\title{
Networking in Autism: Leveraging Genetic, Biomarker and Model System Findings in the Search for New Treatments
}

\author{
Jeremy Veenstra-VanderWeele ${ }^{1,2,3,4}$ and Randy D Blakely ${ }^{\star, 1,3,4}$ \\ ${ }^{1}$ Department of Psychiatry, Vanderbilt University School of Medicine, Nashville, TN, USA; ${ }^{2}$ Department of Pediatrics, \\ Vanderbilt University School of Medicine, Nashville, TN, USA; ${ }^{3}$ Department of Pharmacology, Vanderbilt University School of \\ Medicine, Nashville, TN, USA; ${ }^{4}$ Center for Molecular Neuroscience, Vanderbilt University School of Medicine, Nashville, \\ TN, USA
}

Autism Spectrum Disorder (ASD) is a common neurodevelopmental disorder affecting approximately $1 \%$ of children. ASD is defined by core symptoms in two domains: negative symptoms of impairment in social and communication function, and positive symptoms of restricted and repetitive behaviors. Available treatments are inadequate for treating both core symptoms and associated conditions. Twin studies indicate that ASD susceptibility has a large heritable component. Genetic studies have identified promising leads, with converging insights emerging from single-gene disorders that bear ASD features, with particular interest in mammalian target of rapamycin (mTOR)-linked synaptic plasticity mechanisms. Mouse models of these disorders are revealing not only opportunities to model behavioral perturbations across species, but also evidence of postnatal rescue of brain and behavioral phenotypes. An intense search for ASD biomarkers has consistently pointed to elevated platelet serotonin $(5-\mathrm{HT})$ levels and a surge in brain growth in the first 2 years of life. Following a review of the diversity of ASD phenotypes and its genetic origins and biomarkers, we discuss opportunities for translation of these findings into novel ASD treatments, focusing on mTor- and 5-HT-signaling pathways, and their possible intersection. Paralleling the progress made in understanding the root causes of rare genetic syndromes that affect cognitive development, we anticipate progress in models systems using bona fide ASD-associated molecular changes that have the potential to accelerate the development of ASD diagnostics and therapeutics.

Neuropsychopharmacology Reviews (2012) 37, 196-212; doi: 10.1038/npp.20I I.185; published online 2I September 201 I

Keywords: translation; mGluR5; FMRI; glutamate; serotonin transporter; genetics

\section{ASD HISTORY AND DIAGNOSIS}

Leo Kanner initially described 'early infantile autism' in a case series in 1943, naming the disorder on the basis of the 'autistic aloneness' that he observed in his patients (Kanner, 1943). This social impairment, often considered the defining feature of autism, is intertwined with communication impairment. Nonetheless, these two domains are currently separated in the Diagnostic and Statistical Manual-IV (DSMIV) criteria (American Psychiatric Association, 2000). Truly, however, social function requires verbal or non-verbal

${ }^{*}$ Correspondence: Dr RD Blakely, Center for Molecular Neuroscience, Vanderbilt University School of Medicine, 6133 Medical Research Building III, Suite 7140, MRBIII, Nashville, TN 37232-8548, USA, Tel: +1 615936 3705, Fax: + 1615936 3040,

E-mail: randy.blakely@vanderbilt.edu

Received 20 May 2011; revised 5 August 2011; accepted 6 August 2011 communication, and, reciprocally, communication necessarily includes social interaction. Restricted, repetitive behaviors, which might be considered as the positive symptoms of autism, are also required to make a diagnosis. Symptoms of autism are commonly recognized as a gradual divergence from the expected pattern of development, but some children appear to show a regression, or loss of, previously acquired skills, most often in the second year of life (Werner and Dawson, 2005). Recent work suggests that a decline in social interaction over the first 12-24 months of age may be common in children with autism (Ozonoff et al, 2010), whereas an explicit loss of communication or other skills is less common (Shumway et al, 2011).

Autism and related disorders, now termed pervasive developmental disorders (PDDs), have been diagnosed in a steadily increasing number of children over the past twenty years, with current prevalence estimates nearing $1 \%$ of 
children (Autism and Developmental Disabilities Monitoring Network Surveillance Year 2002 Principal Investigators; Centers for Disease Control and Prevention, 2007). It is not clear how much of this increase is due to broadened criteria, improved diagnostic tools, or other unknown factors. Reflecting the difficulty in finding clear boundaries between the PDDs, the upcoming revision of the DSM (DSM-V at http://DSM5.org) will likely include only one diagnosis, Autism Spectrum Disorder (ASD), instead of separating out Asperger's Disorder and Pervasive Developmental Disorder Not Otherwise Specified (PDD-NOS). This spectrum diagnosis reflects the broad heterogeneity observed across individuals with social communication dysfunction and repetitive behavior.

Each of the three current symptom domains can be quite variable from individual to individual sharing a PDD diagnosis. For example, Lorna Wing and others have noted disparate patterns of social motivation, including children who are socially uninterested or 'aloof', but also children who are socially motivated but qualitatively impaired in their interactions, whom Wing describes as 'active but odd' (Waterhouse et al, 1996). Impairment also varies widely in the communication domain, with a substantial number of children who never achieve verbal speech but others whose speech may be most notable for odd prosody or idiosyncratic phrasing. Finally, the repetitive behavior domain is quite diverse, including intense restricted interests, simple repetitive motor mannerisms, inflexible rituals or routines, or preoccupation with parts of objects, with each child only required to show two of these positive symptoms (American Psychiatric Association, 2000; Richler et al, 2007, 2010). Recent work in sibling pairs affected with autism suggests that individual symptom domains or sub-domains may be separately inherited, particularly in the case of repetitive behavior (Georgiades et al, 2007; Lam et al, 2008; Smith et al, 2009; Tadevosyan-Leyfer et al, 2003).

\section{PERSPECTIVE}

The planned incorporation of a 'spectrum' term in the description of 'ASD' in the DSM-V reflects an extremely complex and heterogeneous syndrome as notable for its variability as for its core features (Figure 1). Surely, the broadening of phenotype is not unique to ASD, as we now recognize that many brain disorders represent clusters of similar but not identical symptoms. No two individuals present with exactly the same features, attesting to the complexity of our genetic heritage, environmental exposure, and brain development and plasticity. With respect to the complexity of autism, we will argue for an integrative approach that seeks to follow systems that are implicated across multiple research modalities. In the space provided,

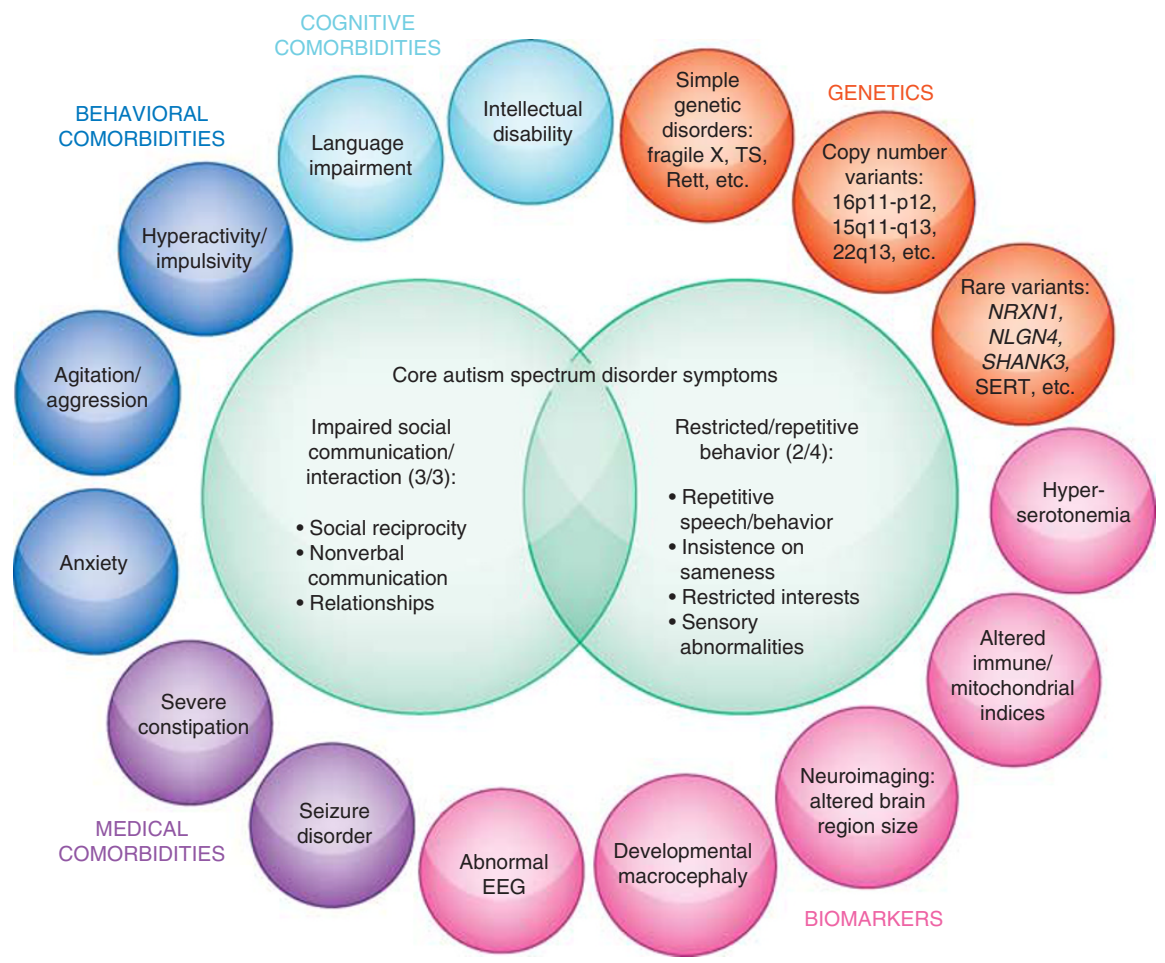

Figure 1. ASD symptoms, comorbidities, and biomarkers. The core symptoms of ASD are represented in the center and represent the common features required to receive a diagnosis. All three social communication/social interaction symptoms are required to receive a diagnosis in the DSM-V draft criteria. This domain represents the 'negative symptoms' of ASD, that is, absence of appropriate social communication. Two of the four restricted/ repetitive behavior symptoms are required to receive a diagnosis in the DSM-V draft criteria. This domain represents the 'positive symptoms' of ASD, that is, the presence of unusual restricted, repetitive, or sensory behaviors. Around the periphery of the figure are symptoms or biomarkers that are not required for an ASD diagnosis but are more common in ASD than in the general populations. Quite a number of comorbid disorders or symptoms are seen in a substantial minority or even a majority of individuals with ASD, spanning cognitive, behavioral/psychiatric, and medical domains. As might be expected from the range of comorbid symptoms, biomarkers and genetic findings also reveal significant heterogeneity across individuals with ASD. 
we cannot enumerate all findings across the relevant research modalities. Instead, after a review of comorbidities that illustrate the complexities of the medical problems of ASD and the limited treatments available, we discuss the genetic and environmental factors reported to impact ASD risk and available ASD biomarkers, particularly those that could drive the search for potential therapeutics. Lastly, we discuss findings within networks that converge on the mammalian target of rapamycin (mTor) pathway and the serotonin (5-hydroxytryptamine, 5-HT) transporter (SERT) as two specific examples of how further preclinical research may provide new opportunities for improved diagnosis and treatment. We refer the reader to other networks and paradigms gaining traction (Bill and Geschwind, 2009; Ehninger et al, 2008b; Levitt and Campbell, 2009; Ramocki and Zoghbi, 2008; Sudhof, 2008), as we expect that multiple avenues will need to be pursued given the heterogeneity of ASD.

\section{COMORBIDITY IN ASD}

Children with ASD frequently show comorbid symptoms that are not part of the diagnostic criteria. These include both general and specific cognitive impairment (Munson et al, 2008). Approximately $1 / 3$ of children with ASD (although with a decreasing ratio as diagnosis increases) show intellectual disability, or IQ two standard deviations below the mean (Chakrabarti and Fombonne, 2005). Specific cognitive deficits have been described in groups of children with ASD, prominently including impairment in executive function (Hill, 2004). Others have posited 'weak central coherence' as a central deficit in ASD, with patients failing to see or understand group relationships (Happe and Frith, 2006).

Changes in sensory function are common in ASD. Some children with ASD show marked hypersensitivity to specific stimuli, whereas others show apparent insensitivity to the environment, including painful stimuli (Baranek et al, 2007; Boyd et al, 2010). A few studies show empirical support for altered sensory processing; although more research is needed in this area (Cascio et al, 2008; Coskun et al, 2009; Kwakye et al, 2011; Tommerdahl et al, 2007).

Epilepsy is common in ASD, with up to $25 \%$ of children affected. The emergence of epilepsy shows two peaks, with some children developing seizures during the first few years of life and a second group developing seizures during adolescence. Beyond those children who have seizures, up to $50 \%$ of children with ASD have an abnormal electroencephalogram (Chez et al, 2006; Hrdlicka et al, 2004; Kim et al, 2006). This observation has led some to hypothesize that there is an imbalance favoring excitatory over inhibitory neurotransmission in ASD (Rubenstein and Merzenich, 2003).

Gastrointestinal symptoms have also received considerable attention in ASD (Buie et al, 2010; Erickson et al, 2005). Despite considerable anecdotal evidence of gastrointestinal dysfunction, available research primarily points to excess constipation and accompanying encopresis (leakage of stool) in ASD (Ibrahim et al, 2009; Wang et al, 2011).

A wide variety of behavioral symptoms are also more commonly seen in ASD than in the general population. Hyperactivity and impulsivity are particularly common and frequently lead to impairment (Simonoff et al, 2008; Volkmar et al, 1999). Aggression and self-injury are also common, particularly in individuals with comorbid intellectual disability (Parikh et al, 2008; Volkmar et al, 1999). Anxiety appears to be more common (Mattila et al, 2010; Simonoff et al, 2008); although current measures have difficulty capturing anxiety symptoms in the ASD population (Wood et al, 2009). Obsessive-compulsive symptoms are also frequent, but these are difficult to separate from the wide range of repetitive behaviors that can be seen in ASD (Jacob et al, 2009; Leyfer et al, 2006).

Overall, the pattern of comorbid symptoms in ASD is broad and matches the heterogeneity in core symptoms. Competing approaches can be taken to the patterns of core and comorbid symptoms. We could, as a field, approach each set of symptoms separately, making each diagnosis that is justified by symptoms (ie, describing a child as having ASD with comorbid epilepsy, constipation-encopresis, sensory aversion, and hyperactivity). Alternatively, we could hypothesize that all of the symptoms most likely reflect a single underlying etiology. Neither approach has clearly won out at this point, but comorbid physical and behavioral symptoms are likely to prove important in separating different causes of ASD.

\section{CURRENT TREATMENT OF ASD}

Unfortunately, available treatments for ASDs are inadequate (McPheeters et al, 2011; Warren et al, 2011). Many children receive treatments based upon applied behavior analysis (ABA), an approach that incrementally reinforces components of core social and communication skills while working to minimize interference from repetitive behavior. Early intensive behavioral interventions that incorporate $30+$ hours per week of therapy using ABA principles may improve symptoms for some children but do not often lead to complete remission of symptoms (Dawson et al, 2010; Smith et al, 2000). Other, less intensive, behavioral interventions targeting social skills have less data to support their use (Beaumont and Sofronoff, 2008; Warren et al, 2011). Some treatment strategies seek to work around deficits by adapting communication systems or educational settings to individual needs (Panerai et al, 2009; Yoder and Lieberman, 2010). Overall, these behavioral interventions are the mainstay of current treatment and do lead to improved function in some children, but they do not cure ASD symptoms in most children (Warren et al, 2011).

Current medications primarily show benefit for comorbid symptoms in ASD, rather than leading to improvement in core symptom domains (McPheeters et al, 2011). Some treatments, such as stimulant medications, may be effective 
in reducing hyperactivity and impulsivity symptoms (Network, 2005). Other treatments, including the atypical antipsychotics risperidone and aripripazole, can effectively target comorbid irritability, agitation, and aggression (Marcus et al, 2009; McCracken et al, 2002). Some evidence shows that atypical antipsychotics may also benefit repetitive behavior symptoms (McDougle et al, 2005). The 5-HT reuptake inhibitors (SRIs) may also provide benefit for distressing repetitive behaviors in some people with ASD, but the data regarding population efficacy are inconsistent (Hollander et al, 2005; King et al, 2009a; McDougle et al, 1996). To date, none of these treatments are based upon a specific understanding of the causes of ASD.

\section{ASD SUSCEPTIBILITY FACTORS}

\section{Genetic Factors}

The path to improved diagnosis and treatment of ASD requires a more sophisticated understanding of biological and environmental susceptibilities. Twin and family studies have demonstrated that heritability has a large role in autism. Beginning with work by Susan Folstein and Michael Rutter in the late 1970s, higher ASD concordance rates have been seen in monozygotic vs dizygotic twins, supporting a heritability of up to $90 \%$ (Bailey et al, 1995; Folstein and Rutter, 1977). More recent twin studies have calculated a lower contribution of heritability (Lichtenstein et al, 2010; Rosenberg et al, 2009), perhaps reflecting changes in diagnostic criteria and population base rate, although heritability estimates remain as high or higher than any other behaviorally defined disorder.

Family studies also support a significant contribution of heritability to autism (Bolton et al, 1994). Again, as diagnosis rates have increased in the general population, recurrence rates within families have increased as well, with estimates ranging from 3 to $11 \%$ in large samples (Bolton et al, 1994; Constantino et al, 2010b; Jorde et al, 1991; Ritvo et al, 1989). Some studies find a much higher rate of subsequent children with ASD in families with two or more affected children, approaching 50\% affected (Zhao et al, 2007). The different patterns of recurrence risk suggest that there are multiple different patterns of inheritance contained within the population of ASD. These patterns may favor different genetic approaches in different subsets of ASD.

Several comprehensive reviews of molecular genetic findings in ASD have been published recently (Bill and Geschwind, 2009; Bourgeron, 2009; Levitt and Campbell, 2009; State, 2011; Weiss, 2009). We will therefore not detail the overall genetic findings in ASD but instead will focus on mTor and 5-HT networks where the biological contexts for therapeutic development are most highly developed. In Table 1, we summarize other findings, including the identification of rare copy-number variants (CNVs) and single-gene variants that represent highly penetrant susceptibility factors, establishing, essentially, new genetic syndromes. Interestingly, some of these findings reveal ASD risk associated with both increased and decreased gene dosage. As might be expected from a gene-to-phenotype approach, the impact of a number of these susceptibility variants does not appear to respect the diagnostic boundaries of ASD and includes risk of intellectual disability, ADHD, or schizophrenia. As tabulated, a number of common polymorphisms have also been associated with ASD; although findings in this area have been slower to emerge.

In addition to specific genetic risk factors, an $\mathrm{XY}$ karyotype confers an increased risk of ASD, with rates at least four times higher in males than females (Fombonne, 2003). This ratio may be further accentuated in children with higher IQ. Reciprocally, the male-to-female ratio appears lower for children with greater degrees of

TABLE 1 Examples of Molecular Genetic Findings in ASD

\begin{tabular}{lll}
\hline Copy-number variants & $\begin{array}{l}\text { Uncommon single-gene } \\
\text { disruptions/mutations }\end{array}$ & $\begin{array}{l}\text { Associations with common } \\
\text { polymorphisms }\end{array}$ \\
\hline $\begin{array}{l}\text { Maternal duplication of } \\
\text { chromosome 15q11-q13 }\end{array}$ & NLGN4X (Jamain et al, 2003) & SEMA5A (Weiss et al, 2009) \\
(Christian et al, 2008; Cook & SHANK3 (Durand et al, 2007) & MET (Campbell et al, 2009, 2006) \\
et al, 1997) & & \\
Deletions or duplications of & SHANK2 (Berkel et al, 2010) & CNTNAP2 (Alarcon et al, 2008; \\
chromosome 16p11 (Kumar & NRXN1 (Bucan et al, 2009; & Arking et al, 2008; Bakkaloglu \\
et al, 2008; Weiss et al, 2008) & Glessner et al, 2009; Kim & et al, 2008) \\
& et al, 2008; Wisniowiecka- & EN2 (Benayed et al, 2005; Brune \\
& Kowalnik et al, 2010) & et al, 2008; Gharani et al, 2004) \\
& PTCHD1 (Noor et al, 2010) & \\
& IL1RAPL1 (Piton et al, 2008) & \\
& SYNGAP1 (Hamdan et al, & \\
& 2011, 2009; Pinto et al, 2010) & \\
& SLC6A4 (Sutcliffe et al, 2005) & \\
\hline
\end{tabular}


intellectual disability. Various hypotheses have been raised regarding the increased risk in males. In the general population, average social communication function is lower in males in comparison with females (Constantino and Todd, 2003; Skuse et al, 2005). Simon Baron-Cohen and coworkers have hypothesized that fetal testosterone exposure may influence social development, with some support from direct and indirect measures of fetal testosterone (BaronCohen, 2010). Skuse et al (1997) explored an alternative hypothesis in Turner Syndrome, where girls have a single $\mathrm{X}$ chromosome. Girls who received their single $\mathrm{X}$ chromosome from their mothers, as is true for all boys, had significantly worse social function than girls who received their X chromosome from their fathers, suggesting that genetic imprinting effects may account for part of the difference in social function. As tabulated, a few genes on the $\mathrm{X}$ chromosome have also been examined for a potential role in ASD. Further analysis of sex-specific risk factors could yield distinct treatments for male and female subjects with ASD, as has been suggested recently for PTSD (Kingwood, 2011; Ressler et al, 2011).

\section{Parental and Prenatal Factors}

Parental and pregnancy factors appear to affect the risk of ASD. Increasing paternal or maternal age increases the risk of $\mathrm{ASD}$, which may relate to a role for de novo genetic variation, including either mutations or CNVs (Durkin et al, 2008; Hultman et al, 2010; King et al, 2009b). Increased loading of pregnancy complications has been reported in children with ASD in comparison with controls; although to date no single complication has been clearly associated with ASD (Gardener et al, 2009). Very low birth-weight or extreme preterm birth also increases the risk of ASD. Evidence suggests that these children may have a different pattern of comorbidities, including intellectual or motor disability, in comparison with the general population of children with ASD (Buchmayer et al, 2009; Limperopoulos et al, 2008; Schendel and Bhasin, 2008; Schieve et al, 2010). One recent study reported an increased risk of ASD following a short inter-pregnancy interval, suggesting a potential role for maternal nutritional status or other gestational factors (Cheslack-Postava et al, 2011).

A couple of rare environmental exposures during pregnancy also increase the risk of ASD (Chess, 1971). Rubella exposure during the first trimester clearly increases the risk of ASD; although congenital rubella syndrome also includes sensorineural deafness, eye abnormalities, intellectual disability, and cardiac malformations (Duszak, 2009). First-trimester exposure to thalidomide also increases risk; although this is also associated with limb, eye, and cardiac malformations (Stromland et al, 1994). Likewise, in utero exposure to valproic acid appears to increase risk; although this is also associated with a broader syndrome including neural tube defects (Williams et al, 2001). One recent study reported an increased risk of ASD following prenatal exposure to SRI medications (fluoxetine, sertraline, etc.), especially during the first trimester (Croen et al, 2011). Further work will be necessary to understand whether this is related to the drugs themselves, or to target symptoms or conditions that are more common in mothers of children with ASD. As a group, these prenatal risk factors are rare causes of ASD, but they suggest a window of vulnerability to environmental agents that increase ASD risk in the first trimester of pregnancy. Additionally, these causes provide opportunities to establish preclinical models whose investigation may uncover key lessons for idiopathic ASD. In this regard, rodent models of in utero viral or valproic acid exposure have been studied and are reviewed elsewhere (Patterson, 2011).

\section{BIOMARKERS IN ASD}

There is a long tradition of biomarker research in ASD. Biomarkers may point toward ASD susceptibility factors in different ways. In theory, a biomarker could contribute directly to susceptibility, but a biomarker also may represent an endophenotype, or a heritable trait resulting from an underlying factor that is the prime contributor to ASD susceptibility (Gottesman and Gould, 2003). Finally, a biomarker may be a secondary result of ASD itself or of ASD treatment. Deciding among these possibilities has therapeutic relevance in narrowing down potential targets and/or using the particular measure as a diagnostic or treatment aid.

The first biomarker described in ASD was elevated wholeblood 5-HT, or hyper-serotonemia, first identified 50 years ago (Schain and Freedman, 1961), and unique to autism among developmental disorders (Hanley et al, 1977; Mulder et al, 2004). Remarkably, gut enterochromaffin cells that synthesize peripheral 5-HT have never been directly assessed in ASD. In the blood, 5-HT is contained almost exclusively in platelets, which acquire 5-HT through the SERT as they pass through the gut circulation. Not surprisingly, whole-blood 5-HT levels are correlated with SERT-mediated 5-HT uptake (Cook et al, 1993; Cross et al, 2008). Additional abnormalities have been found in the platelet in ASD, including decreased radioligand binding to the $5-\mathrm{HT}_{2 \mathrm{~A}}$ receptor (Cook et al, 1993; McBride et al, 1989). Importantly, whole-blood 5-HT levels have been shown to be highly heritable, more heritable than ASD itself (Abney et al, 2001). Postnatal platelet 5-HT is unlikely to directly affect brain function, given its lack of penetration of the blood-brain barrier, but the protein networks regulating peripheral 5-HT homeostasis are largely conserved in the brain. Indeed, the SERT gene (SLC6A4) and the 5 -HT receptor $5-\mathrm{HT}_{2 \mathrm{~A}}$ gene $(H T R 2 A)$ encode the same protein in the platelets and brain (Cook et al, 1994; Lesch et al, 1993). Abnormalities in brain 5-HT systems have also been described in ASD, including an altered developmental trajectory of 5-HT turnover (Chugani et al, 1999) and decreased radioligand binding to both $5-\mathrm{HT}_{2 \mathrm{~A}}$ (Goldberg et al, 2009; Murphy et al, 2006) and SERT (Nakamura et al, 2010). 
The known role of the 5-HT system in brain development raises the possibility that changes in 5-HT homeostasis during development result in altered neuronal migration or neurite outgrowth. As one example, 5-HT modulates thalamocortical axon projections to the sensory cortex, with excessive extracellular 5-HT leading to disruption of the somatosensory map in rodents (Bonnin et al, 2007; Salichon et al, 2001). Recently, Bonnin and colleagues discovered that the placenta synthesizes and releases 5-HT during embryonic brain development at a point before serotonergic raphe axons innervate the forebrain. Moreover, placental release of 5-HT appears to account for the forebrain 5-HT levels at this time, independent of the brain's synthetic capacity (Bonnin et al, 2011). These studies add another dimension to the complex role of 5HT in brain development. Interestingly, the placenta is also a site of high-level expression of SERT proteins (Prasad et al, 1996). Indeed, human SERT was first cloned from placenta (Ramamoorthy et al, 1993), presaging these most recent studies. The recent finding that prenatal exposure to SRIs may increase ASD risk could therefore point to their activity in the maternal circulation, the placenta, or the developing fetal brain (Croen et al, 2011).

Developmental studies of both head circumference and MRI-derived whole-brain size have identified an abnormal rate of brain growth over the first few years in ASD. Using a combination of cross-sectional and longitudinal data, Eric Courchesne and others have identified a surge in brain growth in the first 2 years of life in children with ASD (Courchesne et al, 2003, 2001; Hazlett et al, 2005; Redcay and Courchesne, 2005; Schumann et al, 2010). The cause of this increase in brain growth is unknown, but it appears to be largely symmetric, with increases in both gray matter and white matter (Hazlett et al, 2005; Schumann et al, 2010). A small number of individuals with ASD do have macrocephaly in adulthood, which can be thought of as a separate biomarker (Courchesne et al, 1999), but the majority do not, suggesting a decline in the rate of further brain growth in middle childhood (Courchesne et al, 2011). An increased rate of head growth early in life is also seen in some siblings of children with ASD who do not share the diagnosis, so this trait may also be an endophenotype for ASD (Constantino et al, 2010a; Elder et al, 2008). Interestingly, Joe Piven's group identified an association between an SLC6A4 promoter polymorphism and cortical gray matter overgrowth in children with autism (Wassink et al, 2007), potentially linking compromised 5-HT signaling during development to this well-recognized ASD biomarker.

Structural neuroimaging studies have also sought to identify biomarkers of autism. Regional findings have been inconsistent, but a few patterns may be emerging. First, there appears to be an initial increase in amygdala size in early childhood, followed by a possible decrease in size over time (Kim et al, 2010; Mosconi et al, 2009; Nacewicz et al, 2006; Schumann et al, 2009; Stanfield et al, 2008). Second, there appears to be a general decrease in long-range connectivity (Barnea-Goraly et al, 2010; Frazier and Hardan, 2009; Shukla et al, 2010). These findings are not perfectly consistent, but they have led to a hypothesis of increased local connectivity and decreased distant connectivity (Courchesne and Pierce, 2005). Third, striatal size is increased in multiple studies, with size correlating positively with indices of repetitive behavior (Haznedar et al, 2006; Langen et al, 2007, 2009; Sears et al, 1999). Recent reviews of the structural neuroimaging literature highlight other findings that await consistent replication (Anagnostou and Taylor, 2011; Chen et al, 2011; Stanfield et al, 2008). Ultimately, these structural findings may connect to postmortem neuropathological findings in autism, but sample sizes have been difficult to accrue and data are only just beginning to emerge, initial findings included decreased cortical minicolumn width (Casanova et al, 2002) and decreased GABA receptor binding (Fatemi et al, 2009; Oblak et al, 2011) in ASD subjects.

Functional neuroimaging studies in ASD present significant challenges. First, individuals with more severe impairments are unlikely to tolerate the scanner. Second, the inherent behavioral and cognitive differences in ASD may drive changes in brain response. For example, Richie Davidson's group used eye tracking to show that lower fusiform face area activation corresponded to ASD subjects not looking at the face stimulus while in the scanner (Dalton et al, 2005). Similarly, tasks that probe cognitive deficits in ASD may show differences in brain activation that arise from the deficit itself, or reflect a compensation for the deficit. Basic sensory processing could also be altered in ASD (Foss-Feig et al, 2010; Kwakye et al, 2011; Marco et al, 2011), resulting in abnormal response to almost any stimulus and without specificity for any particular task. Even with these caveats, quite a number of interesting functional neuroimaging findings have been reported that may relate to structural imaging finding, such as altered amgydala response to social stimuli (Kleinhans et al, 2009; Weng et al, 2011). The interested reader is referred to several recent reviews on this topic (Anagnostou and Taylor, 2011; Di Martino et al, 2009).

Additional peripheral biomarkers are beginning to emerge in ASD. For example, much interest has centered on possible mitochondrial dysfunction (Frye and Rossignol, 2011; Giulivi et al, 2010). Although data are accumulating to support the existence of a subgroup of ASD children with such changes, the size of this subgroup and the specificity of these findings remain unclear (Oliveira et al, 2005). Peripheral biomarkers related to the immune system have also generated considerable interest. Whereas evidence suggests that there may be altered immune system function in some children with ASD, the specific alterations appear to vary across studies and will require further analysis to reach consensus (Careaga et al, 2010). Interestingly, SERT proteins are expressed by B-lymphocytes (Faraj et al, 1994; Meredith et al, 2005) and 5-HT signaling contributes to immune system function (Aune et al, 1994; Hofstetter et al, 2005; Young et al, 1993). 


\section{GENETIC SYNDROMES THAT SHOW ASD FEATURES}

Multiple genetic syndromes include ASD symptoms as part of a broader pattern of dysmorphology and medical morbidity. Space does not permit a review of all such syndromes, but here we highlight a few examples (Table 2) that each have a substantial rate of ASD, include macrocephaly as a prominent feature, and affect signaling through the mTor pathway. A comprehensive review by Betancur (2011) provides extensive detail on many other genetic or genomic disorders that may lead to ASD susceptibility.

The most common, inherited cause of ASD is Fragile X syndrome (FraX), an $\mathrm{X}$-linked recessive disorder that is found in $2-3 \%$ of individuals with ASD and is also the most common inherited cause of intellectual disability (Hagerman et al, 2009; Loesch et al, 2007). An expanding trinucleotide repeat in the $5^{\prime}$ untranslated region of the FMR1 gene causes Fragile $\mathrm{X}$ in males (and in some females) with more than 200 copies of the repeat (Kremer et al, 1991). Intellectual disability is a defining feature of FraX, along with a characteristic facial appearance, risk of seizures, and macroorchidism. Behavioral features frequently include hyperactivity, anxiety, sensory sensitivity, and avoidance of eye contact (Hagerman et al, 2009). Approximately $60 \%$ of individuals with FraX meet the criteria for ASD; although patterns of symptoms differ from the general ASD population (Hall et al, 2010; Harris et al, 2008). As reviewed below and elsewhere (Bhogal and Jongens, 2010; Heulens and Kooy, 2011), significant progress has been made in understanding the molecular changes that connect loss of FMR1 expression to the observed neurological, cognitive, and behavioral abnormalities in the mouse model. Prominent among the networks disturbed by loss of FMR1 is the mTor pathway and associated translational control mechanisms (Penagarikano et al, 2007; Sharma et al, 2010).

Three additional single-gene disruption disorders cause excessive signaling through the mTor pathway and lead to increased risk of ASD, as reviewed below (Figure 2). PTEN mutations lead to a hamartoma tumor syndrome as well as macrocephaly, and often ASD (Butler et al, 2005; Goffin et al, 2001). Mice lacking PTEN expression in neurons show deficient sociability (Kwon et al, 2006; Zhou et al, 2009), as do mice with hemizygous constitutive PTEN knockout (KO) (Page et al, 2009). Interestingly, and with relevance to our subsequent section on potential 5-HT mechanisms in ASD, PTEN and SLC6A4 cooperatively exacerbate brain size and sociability phenotypes (Page et al, 2009). Tuberous sclerosis is caused by mutations in either hamartin (TSC1) or tuberin (TSC2) (Consortium, 1993; van Slegtenhorst et al, 1997). Each of these syndromes, as well as related syndromes further upstream or downstream from mTor signaling (Table 1 and Figure 2), result in macrocephaly, a potential connection with this transient biomarker in ASD. As reviewed below, exciting research suggests that targeting control mechanisms for the mTor pathway may benefit individuals with these syndromes, and perhaps idiopathic ASD as well.

\section{PATH FROM RARE GENETIC SYNDROMES TO NEW TREATMENTS IN ASD}

\section{mTor and Regulation of Protein Synthesis}

A major goal of preclinical studies of ASD susceptibility genes is the translation of disrupted signaling pathways to medications that can relieve physiological and behavioral deficits. In the past, such a challenge seemed naive, as

TABLE 2 Genetic Syndromes that Affect mTor Signaling and Increase Risk of ASD

\begin{tabular}{|c|c|c|c|}
\hline Syndrome & Gene & Common symptoms & Effect on mTor \\
\hline $\begin{array}{l}\text { PTEN hamartoma tumor } \\
\text { syndrome }\end{array}$ & PTEN & $\begin{array}{l}\text { Macrocephaly } \\
\text { Hamartomas in } \\
\text { multiple organs } \\
\text { Lipomas } \\
\text { Cancer risk }\end{array}$ & Disinhibition \\
\hline Tuberous sclerosis & TSC1, TSC2 & $\begin{array}{l}\text { Macrocephaly } \\
\text { Hamartomas in } \\
\text { multiple organs } \\
\text { Renal cysts and } \\
\text { angiomyolipomas } \\
\text { Facial angiofibromas }\end{array}$ & Disinhibition \\
\hline Neurofibromatosis, type-I & NF1 & $\begin{array}{l}\text { Macrocephaly } \\
\text { Fibromatous skin tumors } \\
\text { CNS tumors }\end{array}$ & Disinhibition \\
\hline Fragile $X$ syndrome & FMR1 & $\begin{array}{l}\text { Macrocephaly } \\
\text { Macroorchidism } \\
\text { Risk of seizure disorder }\end{array}$ & $\begin{array}{l}\text { Disinhibition of } \\
\text { downstream gene } \\
\text { regulation }\end{array}$ \\
\hline
\end{tabular}




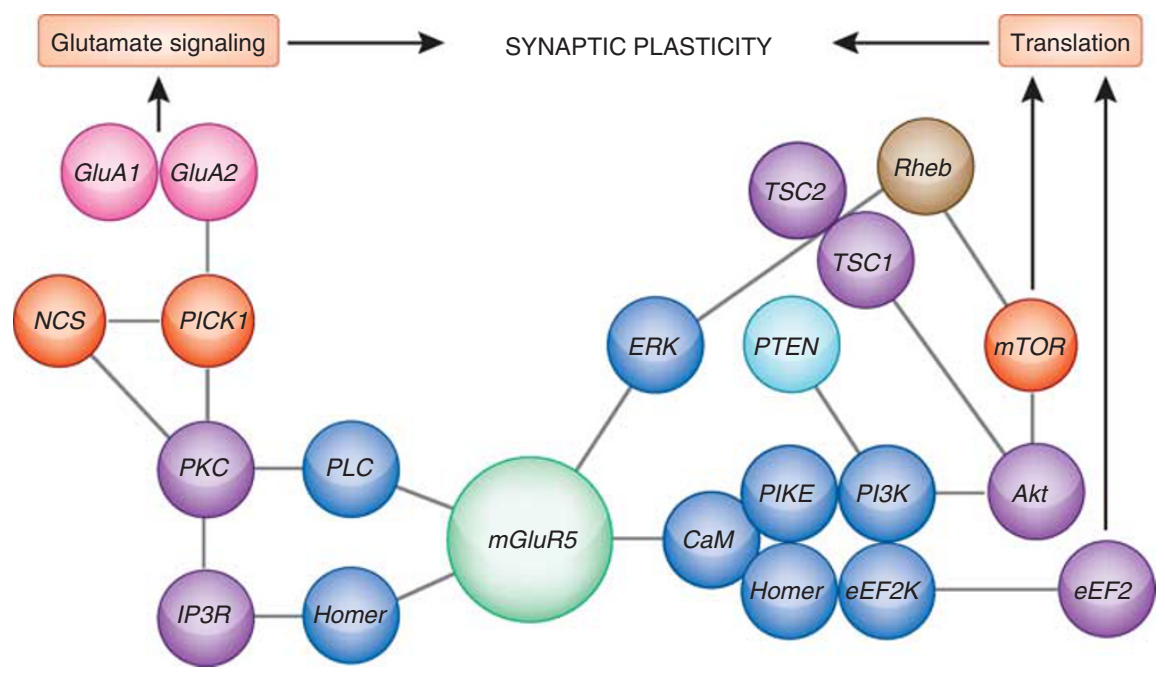

Figure 2. Network of gene products connecting glutamate signaling to translation and synaptic plasticity. The network shown represents physical and signaling interactions between the gene products noted. mGluR5 is centrally located in this illustration to note its capacity for the regulation of both glutamate signaling through ionotropic glutamate receptors and mRNA translation through mTOR-linked signaling pathways. Convergence of FMR1 and TSC1/TSC2 gene products altered that signal through mTOR-linked translation control pathways, independent of mGluRs, are also shown.

lifelong alterations in cognitive function and social reciprocity were believed to derive from irreversible modifications of neuronal wiring established during early brain development. Initial findings suggest that, although the micro-circuitry of the brain in ASD subjects may be altered, deficits in synaptic signaling and plasticity may be of greater significance. The implications of this perspective are not insignificant as they raise the prospect that ASD traits could be ameliorated if the mechanisms compromised can be identified. Adding optimism to this idea, studies with transgenic mouse models of single-gene disorders that bear ASD features have demonstrated remarkable reductions, and in some cases elimination of behavioral deficits following either genetic and/or pharmacological manipulations (Ehninger et al, 2008a; Guy et al, 2007; Tropea et al, 2009; van Woerden et al, 2007; Zhou et al, 2009). A comprehensive review of these findings has been published recently (Ehninger et al, 2008b). As we do not cover them here, the interested reader should pay particular attention to mouse models of neurofibromatosis and Rett syndrome, where striking reversals of behavioral deficits have been achieved in mature animals (Ehninger et al, 2008a; Li et al, 2005). Here, we outline other instances of such success to highlight the promise that basic research offers for the treatment of ASDs, with reference to pathways linked to mTOR and 5-HT signaling.

As noted above, tuberous sclerosis, derived from heterozygous inactivation of TSC1 or TSC2, presents with ASD features. The diagnostic features of this disorder are epithelial growths ('tubers') visible on MRI scans. However, studies fail to correlate the abundance of tubers with cognitive deficits in humans and in mouse models (Numis et al, 2011). Most recently these deficits have been found to derive from neuronal signaling alterations associated with disrupted mTOR signaling. TSC1 and TSC2 form a hetero- dimeric complex that negatively regulates mTOR-signaling pathways that control protein translation. Protein synthesis within synaptic spines is a key feature of the long-term plasticity of neurons and is now known to be required for proper cognitive function, as well as the actions of chronically administered antidepressant medications ( $\mathrm{Li}$ et al, 2010). Ehninger et al reasoned that constitutively elevated mTOR signaling could be offset by rapamycin, an mTOR inhibitor. Remarkably, they achieved reversal of deficits in spatial learning and context discrimination with brief (5 day) postnatal administration of rapamycin (Ehninger et al, 2008a). These studies nicely converge with studies involving manipulation of the lipid phosphatase PTEN, an upstream regulator of the TSC1/TSC2-mTOR pathway, which also can produce amelioration of the structural and neurological features of ASD in mouse models (Zhou et al, 2009).

The paradigmatic disorder with ASD features that links to protein translation is FraX (Kremer et al, 1991). The FMR1 protein (FMRP) binds to mRNAs and regulates their transport and translation (Ashley et al, 1993; Eberhart et al, 1996). Huber et al (2002) first identified changes in long-term depression, a form of synaptic plasticity, in Fmr1-KO mice that is mediated by hyperactivity of metabotropic glutamate receptor type-5 (mGluR5) signaling and linked to the translation and trafficking of AMPA subtype glutamate receptors. These studies led Bear and colleagues (2004) to propose the 'mGluR theory' of FraX, positing that, in the absence of FMRP, mGluR1/5 stimulation results in excessive protein synthesis, thereby leading to excessive trafficking of AMPA receptors away from the cell surface. These investigators tested their hypothesis by decreasing the normal expression of mGluR5 (Dolen et al, 2007), demonstrating a remarkable reversal of protein synthesis, dendritic spine alterations, and multiple 
behavioral phenotypes. These studies provide robust that manipulation of mGluR5-signaling pathways could provide relief for multiple aspects of FraX. They also provide a cogent example of how context can dramatically impact the penetrance of otherwise devastating genetic changes.

Consistent with the ability of a partial loss of mGluR5 to reverse cognitive deficits of Fmr1-deficient mice, the mGluR1/5 antagonist MPEP reverses multiple behavioral abnormalities in Fmr1-null mice (de Vrij et al, 2008; Levenga et al, 2011; Yan et al, 2005). Remarkably, Su et al (2011) recently reported that early, continuous, treatment with MPEP can even reverse dendritic spine abnormalities in Fmr1-KO mice. One preliminary clinical study of an mGluR5 antagonist in adult FraX subjects showed some promise, but only in the subgroup that had complete FMR1 methylation (Jacquemont et al, 2011). Additional trials of mGluR5 antagonists in FraX are ongoing. The use of MPEP to treat features of ASDs may well extend beyond genetic disruptions in Fmr1. Thus, Jacki Crawley's group has observed that MPEP can reverse repetitive grooming behavior in the BTBR inbred strain of mice (Silverman et al, 2010). Interestingly, loss of the Drosophila Fmr1 homolog leads to elevated dopamine and 5-HT synthesis (Zhang et al, 2005). Gruss and Braun (2001) reported only modest correlates of these changes in monoamines in the Fmr1-null mouse; although we must remember that tissue levels provide a limited window on monoamine signaling in vivo. Further, the behavioral actions of 5-HT-elevating antidepressants have been linked to mTOR activation (Li et al, 2010) and alleles of 5HTTLPR have been found to associate with elevated aggression and destructive behavior in FraX patients (Hessl et al, 2008). These findings suggest that features of altered 5-HT signaling, either with respect to early developmental signaling or enduring functional modulation, may derive in part from 5-HT signaling through the mTOR pathway. In this regard, Cleary et al (2008) found that the mTOR inhibitor rapamycin exerts activity typical of an SRI in animal models in suppressing struggling in both the forced-swim and tail suspension tests.

In summary, multiple single-gene disorders with ASD features derive from compromised regulation of mTORlinked signaling pathways. Whether deficits associated with idiopathic ASD derive from these pathways remains to be clarified. The heterogeneity of ASD should at the outset suggest that subgroups, behaviorally or molecularly defined, will likely need to be considered in therapeutic development. The search for synaptic signaling networks that control or are altered by mTOR signaling has revealed mGluR5 as a target whose manipulation can be projected to produce less side effects than targeting mTOR more directly. MPEP itself is likely a 'proof-of-concept' drug, most useful for preclinical animal studies. Additionally, only a limited number of behavioral features and synaptic alterations of ASD models have been queried for responsiveness to mGluR5 manipulation. With respect to the latter point, Suvrathan et al (2010) have recently extended the utility of MPEP for mGluR5 manipulation in reversing presynaptic deficits in the amygdala, work that could have relevance for changes in amygdala function in ASD. Finally, mGluR5 is likely but one 'druggable' target, including other surface receptors (eg, IL-1Rs), whose signaling can impact mTOR networks and thus be targeted for potential therapeutics. Interestingly, IL-1Rs have also emerged with respect to control of 5-HT signaling, as discussed below. We suspect that in the coming years, the study of this and other targets will contribute further momentum to an already active area of mTOR-targeted research.

\section{FROM A BIOMARKER TO GENETIC VARIATION TO NEW TREATMENTS FOR ASD?}

\section{SERT-Mediated 5-HT Homeostasis}

Based on the strong heritability of whole-blood 5-HT levels, Ed Cook and Carole Ober's labs mapped quantitative trait loci (QTLs) in a large founder population, revealing association with ITGB3, which encodes the SERT-associated protein integrin- $\beta 3$ (Weiss et al, 2004). A follow-up scan revealed association of both ITGB3 and SLC6A4 with wholeblood 5-HT specifically in males (Weiss et al, 2005). Multiple linkage scans in ASD have shown significant evidence for linkage in the chromosome $17 \mathrm{q}$ region containing SLC6A4 (International Molecular Genetic Study of Autism Consortium, 2001; McCauley et al, 2004; Stone et al, 2004; Sutcliffe et al, 2005). Sutcliffe et al (2005) showed that this linkage evidence is confined to families containing two or more affected males and no affected females, paralleling the QTL data for hyper-serotonemia noted above. As common SLC6A4 variants did not explain the strong linkage signal on $17 \mathrm{q}$, the Sutcliffe and Blakely labs searched for rare variants (Sutcliffe et al, 2005) and identified multiple, rare non-synonymous variants, with each demonstrating increased 5-HT uptake (Prasad et al, 2009, 2005). Interestingly, Dennis Murphy's group identified an SERT variant, Ile425Val, that segregates with obsessive-compulsive disorder (OCD) (as well as other neuropsychiatric disorders including Asperger's syndrome) in two unrelated pedigrees (Ozaki et al, 2003). Gary Rudnick's group established that Ile425Val shows constitutively elevated 5-HT transport activity (Kilic et al, 2003).

\section{Targeting Altered 5-HT Signaling in ASD}

Following a model of diminished synaptic 5-HT availability, one would predict that agents that reduce $5-\mathrm{HT}$ availability would negatively impact ASD subjects, whereas SRIs should be beneficial. Consistent with this idea, short-term tryptophan depletion worsens ASD symptoms (McDougle et al, 1993). Three small, randomized, placebo-controlled trials have found beneficial effects of the SRIs clomipramine, fluvoxamine, and fluoxetine for OCD-like behavior in ASD (Gordon et al, 1993; Hollander et al, 2005; McDougle et al, 
TABLE 3 Serotonin Metabolism and Transport Genes

\begin{tabular}{lll}
\hline Gene & Protein & Action \\
\hline TPH1 & Tryptophan hydroxylase-1 & $\begin{array}{l}\text { Rate-limiting enzyme in 5-HT synthesis in the } \\
\text { periphery, converts tryptophan to 5-hydroxy- } \\
\text { tryptophan }\end{array}$ \\
TPH2 & Tryptophan hydroxylase-2 & $\begin{array}{l}\text { Rate-limiting enzyme in 5-HT synthesis in } \\
\text { serotonergic neurons, converts tryptophan to } \\
\text { 5-hydroxy-tryptophan }\end{array}$ \\
& $\begin{array}{l}\text { Aromatic L-amino acid } \\
\text { DDC }\end{array}$ & $\begin{array}{l}\text { Enzyme in 5-HT and dopamine synthesis, converts } \\
\text { 5-hydroxy-tryptophan to 5-HT }\end{array}$ \\
VMAT2 & $\begin{array}{l}\text { Vesicular monoamine } \\
\text { transporter, type-2 }\end{array}$ & $\begin{array}{l}\text { Transports 5-HT into pre-synaptic vesicles in a } \\
\text { proton-dependent manner }\end{array}$ \\
SLC6A4 & Serotonin transporter (SERT) & $\begin{array}{l}\text { Transports 5-HT into the pre-synaptic neuron in a } \\
\text { sodium-dependent manner }\end{array}$ \\
& Monoamine oxidase & $\begin{array}{l}\text { Converts 5-HT to 5-hydroxyindoleacetic acid (5-HIAA), } \\
\text { its primary metabolite }\end{array}$ \\
\hline
\end{tabular}

1996). By contrast, one large, randomized trial reported no efficacy for the SRI citalopram for repetitive behavior in ASD subjects (King et al, 2009a). Additional studies are needed that use selection criteria based on biomarkers, genotypes, or more specific impairing symptoms. The hyper-functional SERT variants were found in individuals with high scores on measures of rigid-compulsive traits and sensory aversion (Sutcliffe et al, 2005), suggesting that SERT blockade might be most beneficial for these individuals. Despite the appeal of SRIs as available drugs, however, complete blockade of SERT is likely to overshoot a modulated restoration of 5 -HT homeostasis (Table 3 ). Below we discuss the network of gene products that regulate SERT where novel therapeutics could be developed that conditionally diminish SERT activity, permitting SERT to maintain a basal level of control over synaptic 5-HT.

Prominent pathways that regulate SERT trafficking and catalytic function include those linked to PKC, PKG, and p38 MAPK signaling (Samuvel et al, 2005; Steiner et al, 2009; Zhu et al, 2005) (Figure 3). Importantly, many of the rare SERT coding variants show altered sensitivity to these signals (Prasad et al, 2009, 2005). Certainly these networks, like mTOR pathways, are widespread and have many targets, making their therapeutic manipulation problematic. As with mTOR, however, there are ways to enter these pathways in a more cell-specific manner. For example, brain SERT activity can be enhanced by adenosine-A3 and Il-1 $\beta$ receptors (A3AR and IL-1R), with loss of regulation evident in A3AR and IL-1R-KO mice, respectively (Zhu et al, 2010, 2007). A3ARs signal to SERT through PKG and p38 MAPK, whereas IL-1Rs bypass PKG to activate p38 MAPK directly.

Given the capacity of A3AR and IL-1R activation to mimic the elevated 5-HT transport activity observed constitutively in ASD-associated SERT coding variants, it appears reasonable to consider whether pharmacological modulation of A3AR- or IL-1R-signaling pathways could lead to novel ASD therapeutics. Although a connection between IL-1Rs and 5-HT signaling is growing (Capuron and Miller, 2011; Zhu et al, 2011), we focus our discussion here on A3ARs. Among the CNS adenosine receptor subtypes, A3ARs are the least studied, receiving more attention in the control of peripheral immune function and inflammation (Hasko et al, 2008). Indeed, early investigators questioned whether A3ARs exist in the brain at all (Rivkees et al, 2000). However, more recent efforts have established clear actions of A3AR agonists in protection of the CNS against hypoxia/ischemic and inflammatory insults (Borea et al, 2009; Haas and Selbach, 2000; Taliani et al, 2010), as well as support for synaptic signaling and plasticity (Brand et al, 2001; Costenia et al, 2001; Dunwiddle et al, 1997; Macek et al, 1998).

Recently, Zhu et al (2011) demonstrated that SERT and A3ARs colocalize in raphe neurons and can form an A3AR agonist-sensitive physical complex, providing further rationale to pursue pharmacological manipulation of A3ARlinked signaling for 5-HT-associated disorders. Trials of the A3AR-selective agonist CF 101 (IB-MECA) have been initiated and the agent has been found to be well-tolerated and capable of anti-inflammatory effects. Future studies will hopefully explore the action of this agent on behaviors supported by CNS 5-HT signaling. Additional proteins that coordinate A3AR signaling to SERT (Figure 3) should also be considered as potential therapeutic targets. SERTs exist in physical complexes with other signaling, scaffolding, and cytoskeletal proteins. Among these are NOS1 that produces nitric oxide to activate guanyl cyclase, producing cGMP and thereby activating the cGMP-responsive kinase PKG1 $\alpha$ (Carneiro and Blakely, 2006; Carneiro et al, 2008; Chanrion 


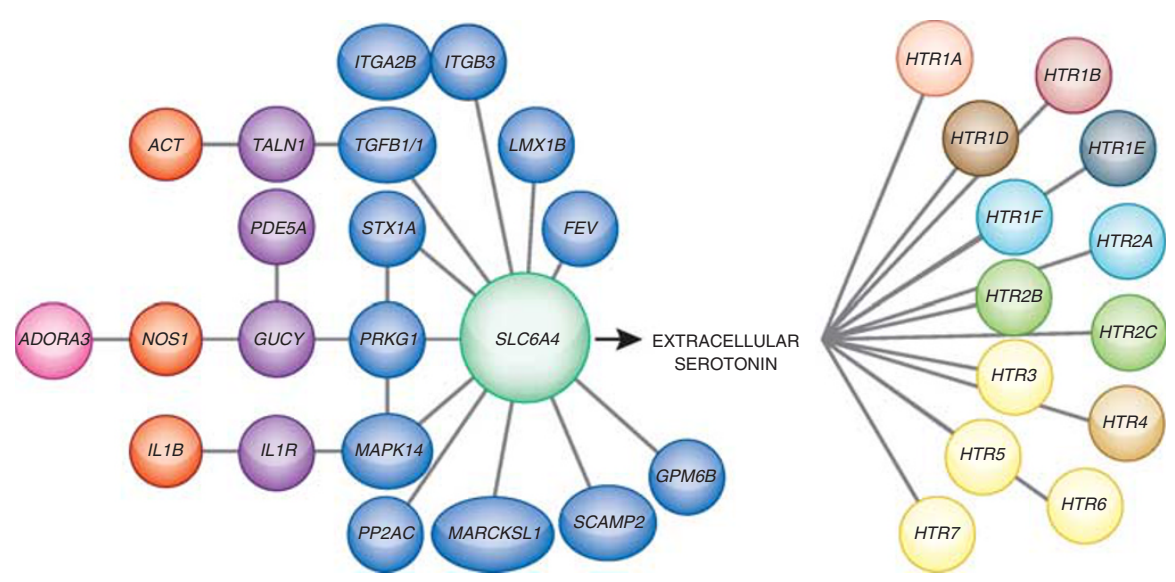

Figure 3. Network of gene products regulating the expression, trafficking, and activity of the antidepressant-sensitive 5-HT transporters (SERT, SLC6A4). SERT controls the extracellular availability of 5-HT in the brain and periphery, and also recycles serotonin for further rounds of release. SERTmediated clearance of 5-HT limits the amplitude and duration of signaling of more than a dozen 5-HT receptors. We hypothesize that just as risk for ASD can derive from genetic variation in SERT that impacts 5-HT signaling during brain development, risk for ASD can also be generated through environmental or genetic perturbations of SERT-regulatory control mechanisms.

et al, 2007; Quick, 2003; Steiner et al, 2009). Phosphodiesterases, such as PDE2, 5, and 9, hydrolyze cGMP, thereby reducing PKG stimulation of SERT. Agents that manipulate one or more of these steps in the A3AR-signaling pathway to SERT may provide novel approaches to normalize 5-HTassociated behavioral deficits.

Paralleling efforts to model disruptions in mTor-regulatory pathways using mouse models, we have produced SERT Ala56-knock-in mice, introducing the most common of the hyper-functional ASD SERT variants into the native SERT gene locus (Veenstra-VanderWeele et al., unpublished data (submitted)). Importantly, SERT Ala56 mice show hyper-serotonemia and enhanced rates of 5-HT clearance in vivo, as predicted from findings of elevated 5-HT transport in vitro. As seen with the variant in transfected cells, mid-brain SERT Ala56 protein shows p38 MAPK-dependent hyper-phosphorylation, further linking physiological alterations to the SERT-regulatory network discussed above. SERT Ala56 mice show hypersensitivity at 5-HT1A and 5-HT2A receptors that likely arises as compensation for decreased synaptic 5-HT availability. Finally, we observe abnormalities in social, communication, and repetitive behavior in the SERT Ala56 mice, opening the door to detailed mechanistic studies in a model of autism with both face and construct validity. Studies are underway to understand the developmental $v s$ dynamic effects of the SERT Ala56 variant in these animals, and to explore whether the physiological and behavioral alterations seen can be reversed. 5-HT1A- and 5-HT2A-based agents should be considered given the altered receptor sensitivities noted in the SERT Ala56 mice. Both receptors are currently targeted by pharmacologically complex agents such as risperidone ( $\mathrm{D}_{2}$ and $5-\mathrm{HT}_{2 \mathrm{~A} / 2 \mathrm{C}}$ antagonist, etc.), which is effective for treatment of irritability in autism (McCracken et al, 2002; McPheeters et al, 2011), and buspirone (5- $\mathrm{HT}_{1 \mathrm{~A}}$ partial agonist; $D_{2}, \alpha_{1}, \alpha_{2}$ antagonist, etc.), which is under study in a large, randomized trial in autism (Edwards et al, 2006).

\section{SUMMARY}

ASD is a heterogeneous and multi-factorial condition, and identifying subgroups of individuals will be necessary to gain traction into its pathophysiology and novel opportunities for treatment. Possible subgroups can be identified based on biomarkers, such as macrocephaly or indicators of mitochondrial dysfunction, or genetic findings, such as the neurexin-neuroligin system. Two of the established ASD subgroups are based on abnormal mTOR and 5-HT signaling in some individuals with ASD. These two networks represent opportunities to move from genetic and biomarker findings to model systems that allow studies of mechanisms and potential novel treatments for ASD. Multiple single-gene disorders with ASD features converge on altered control of mTOR signaling. Elegant work on the connection of mTOR signaling to glutamate-supported synaptic plasticity has led to considerations of regulatory glutamate receptors, particularly mGluR5, as a potential target for novel ASD medications. Hyper-serotonemia has now reached its 50th anniversary as a biomarker in ASD, compelling consideration of recent genetic studies that point to dysregulation of SERT and/or its regulatory networks. ASD-associated SERT coding variants provide a framework to better understand the contribution of altered 5-HT homeostasis to brain development and ASD-related behavior. We suggest future consideration of agents that engage proteins mediating SERT stimulation by A3ARs (eg, A3AR, NOS1, PKG1, p38 MAPK) but remind ourselves that, as with targeting mTOR pathways, the heterogeneity of ASD will likely require multiple approaches that are tailored to individuals with specific symptoms, genetics, and biomarker profiles. 


\section{FUTURE RESEARCH DIRECTIONS}

It is clear that new therapies are desperately needed for ASD. We believe that the soundest way forward is to follow the biology and decode its messages, whether they are established by genetics, the environment, or the continual dialog between the two. From single-gene disorders with ASD features comes a realization that the mTOR-signaling network may have many nodes where ASD risk is embedded. From biomarker, developmental, and genetic studies comes a reminder of how much, despite decades of study, we still have to learn about 5-HT, such as whether its signaling regulators might themselves represent one such node of the mTOR pathway and vice versa. Should this prove to be the case, agents that target specific 5-HT receptors and their signaling partners may prove beneficial in ASD treatment. As with mGluR5 and mTOR, the biology of 5-HT signaling can teach us how to target widespread signaling pathways in nuanced ways that can offer more help than harm. In that light, we suggest that targeting of SERT-regulatory pathways, as opposed to the pharmacological bludgeoning of the transporter itself, as with SRIs, may offer options for ASD treatments. Clearly, new animal models are needed, particularly those that result from environmental or genetic perturbations that lead to ASD traits in some individuals, as in the use of rare, penetrant coding mutations in genes expressed in brain areas impacted by the disorder, early in development. The era of trying to use animals with odd behaviors as models for neuropsychiatric disease is drawing to a close. Just because there is evidence of mitochondrial dysfunction or changes in the immune system, does not mean that we can accept any model that generates such changes. We can do better. Our models must be increasingly linked to the explicit mechanisms responsible for these changes, at least in some ASD subjects. Finally, we have noted above the intersections emerging between mTOR and 5-HT networks in the brain. There are observations outside the CNS that suggest similar convergences (eg, Soll et al, 2010). The study of 5-HT has long captured the interest of translational researchers. The elucidation of translational mechanisms influenced by a convergence of 5-HT/mTOR-signaling pathways may further fuel this interest.

\section{ACKNOWLEDGEMENTS}

We thank Nicholas Campbell for assistance with illustrations and the NIH for the awards MH081066 and MH094604 to JVV, and MH078028, MH094527, and HD065278 to RDB.

\section{DISCLOSURE}

Dr Veenstra-VanderWeele has received research funding from Seaside Therapeutics, Roche Pharmaceuticals, and Novartis. RDB has received research funding from Forest Pharmaceuticals, and serves on the Lundbeck Pharmaceuticals Advisory Board and as a consultant to JubilantInnovation.

\section{REFERENCES}

Autism and Developmental Disabilities Monitoring Network Surveillance Year 2002 Principal Investigators; Centers for Disease Control and Prevention (2007). Prevalence of autism spectrum disorders - autism and developmental disabilities monitoring network, 14 sites, United States, 2002. MMWR Surveill Summ 56: $12-28$.

Abney M, McPeek MS, Ober C (2001). Broad and narrow heritabilities of quantitative traits in a founder population. Am J Hum Genet 68: 1302-1307.

Alarcon M, Abrahams BS, Stone JL, Duvall JA, Perederiy JV, Bomar JM et al (2008). Linkage, association, and gene-expression analyses identify CNTNAP2 as an autism-susceptibility gene. Am J Hum Genet 82: 150-159.

American Psychiatric Association (2000). Diagnostic and Statistical Manual of Mental Disorders-Text Revision (DSM-IV-TR) 4th edn. American Psychiatric Association Press Inc.: Washington, DC.

Anagnostou E, Taylor MJ (2011). Review of neuroimaging in autism spectrum disorders: what have we learned and where we go from here. Mol Autism 2: 4.

Arking DE, Cutler DJ, Brune CW, Teslovich TM, West K, Ikeda M et al (2008). A common genetic variant in the neurexin superfamily member CNTNAP2 increases familial risk of autism. Am J Hum Genet 82: 160-164.

Ashley CT, Wilkinson KD, Reines D, Warren ST (1993). FMR1 protein: conserved RNP family domains and selective RNA binding. Science 262: 563-566.

Aune TM, Golden HW, McGrath KM (1994). Inhibitors of serotonin synthesis and antagonists of serotonin $1 \mathrm{~A}$ receptors inhibit $\mathrm{T}$ lymphocyte function in vitro and cell-mediated immunity in vivo. J Immunol 153: 489-498.

Bailey A, Le Couteur A, Gottesman I, Bolton P, Simonoff E, Yuzda E et al (1995). Autism as a strongly genetic disorder: evidence from a British twin study. Psychol Med 25: 63-78.

Bakkaloglu B, O'Roak BJ, Louvi A, Gupta AR, Abelson JF, Morgan TM et al (2008). Molecular cytogenetic analysis and resequencing of contactin associated protein-like 2 in autism spectrum disorders. Am J Hum Genet 82: 165-173.

Baranek GT, Boyd BA, Poe MD, David FJ, Watson LR (2007). Hyperresponsive sensory patterns in young children with autism, developmental delay, and typical development. Am J Ment Retard 112: 233-245.

Barnea-Goraly N, Lotspeich LJ, Reiss AL (2010). Similar white matter aberrations in children with autism and their unaffected siblings: a diffusion tensor imaging study using tract-based spatial statistics. Arch Gen Psychiatry 67: 1052-1060.

Baron-Cohen S (2010). Empathizing, systemizing, and the extreme male brain theory of autism. Prog Brain Res 186: 167-175.

Bear MF, Huber KM, Warren ST (2004). The mGluR theory of fragile $X$ mental retardation. Trends Neurosci 27: 370-377. First publication of the hypothesis that dysregulated signaling through metabotropic glutamate receptors mediates abnormal brain function in Fragile $X$ Syndrome.

Beaumont R, Sofronoff K (2008). A multi-component social skills intervention for children with Asperger syndrome: the Junior Detective Training Program. J Child Psychol Psychiatry 49: 743-753.

Benayed R, Gharani N, Rossman I, Mancuso V, Lazar G, Kamdar S et al (2005). Support for the homeobox transcription factor gene ENGRAILED 2 as an autism spectrum disorder susceptibility locus. Am J Hum Genet 77: 851-868.

Berkel S, Marshall CR, Weiss B, Howe J, Roeth R, Moog U et al (2010). Mutations in the SHANK2 synaptic scaffolding gene in autism spectrum disorder and mental retardation. Nat Genet 42: 489-491.

Betancur C (2011). Etiological heterogeneity in autism spectrum disorders: more than 100 genetic and genomic disorders and still counting. Brain Res 1380: 42-77. Comprehensive review of the many genomic regions and genes implicated in individuals with ASD.

Bhogal B, Jongens TA (2010). Fragile X syndrome and model organisms: identifying potential routes of therapeutic intervention. Dis Model Mech 3: 693-700.

Bill BR, Geschwind DH (2009). Genetic advances in autism: heterogeneity and convergence on shared pathways. Curr Opin Genet Dev 19: 271-278.

Bolton P, Macdonald H, Pickles A, Rios P, Goode S, Crowson M et al (1994). A case-control family history study of autism. J Child Psychol Psychiatry 35: 877-900

Bonnin A, Goeden N, Chen K, Wilson ML, King J, Shih JC et al (2011). A transient placental source of serotonin for the fetal forebrain. Nature 472: 347-350. Exciting new findings that 5-HT made in the placenta reaches the brain and has effects on forebrain development.

Bonnin A, Torii M, Wang L, Rakic P, Levitt P (2007). Serotonin modulates the response of embryonic thalamocortical axons to netrin-1. Nat Neurosci 10: 588-597. Important evidence of the neurodevelopmental actions of serotonin.

Borea PA, Gessi S, Bar-Yehuda S, Fishman P (2009). A3 adenosine receptor: pharmacology and role in disease. Handb Exp Pharmacol 193: 297-327.

Bourgeron T (2009). A synaptic trek to autism. Curr Opin Neurobiol 19: 231-234. Review of the involvement of synaptic adhesion proteins and their interacting proteins in ASD. 
Boyd BA, Baranek GT, Sideris J, Poe MD, Watson LR, Patten E et al (2010). Sensory features and repetitive behaviors in children with autism and developmental delays. Autism Res 3: 78-87.

Brand A, Vissiennon Z, Eschke D, Nieber K (2001). Adenosine $A(1)$ and $A(3)$ receptors mediate inhibition of synaptic transmission in rat cortical neurons. Neuropharmacology 40: 85-95.

Brune CW, Korvatska E, Allen-Brady K, Cook Jr EH, Dawson G, Devlin B et al (2008). Heterogeneous association between engrailed-2 and autism in the CPEA network. Am J Med Genet B Neuropsychiatr Genet 147B: 187-193.

Bucan M, Abrahams BS, Wang K, Glessner JT, Herman El, Sonnenblick LI et al (2009). Genome-wide analyses of exonic copy number variants in a family-based study point to novel autism susceptibility genes. PLoS Genet 5: e1000536.

Buchmayer S, Johansson S, Johansson A, Hultman CM, Sparen P, Cnattingius S (2009). Can association between preterm birth and autism be explained by maternal or neonatal morbidity? Pediatrics 124: e817-e825.

Buie T, Campbell DB, Fuchs III GJ, Furuta GT, Levy J, Vandewater J et al (2010). Evaluation, diagnosis, and treatment of gastrointestinal disorders in individuals with ASDs: a consensus report. Pediatrics 125(Suppl 1): S1-18.

Butler MG, Dasouki MJ, Zhou XP, Talebizadeh Z, Brown M, Takahashi TN et al (2005). Subset of individuals with autism spectrum disorders and extreme macrocephaly associated with germline PTEN tumour suppressor gene mutations. J Med Genet 42: 318-321.

Campbell DB, Buie TM, Winter H, Bauman M, Sutcliffe JS, Perrin JM et al (2009). Distinct genetic risk based on association of MET in families with co-occurring autism and gastrointestinal conditions. Pediatrics 123: 1018-1024.

Campbell DB, Sutcliffe JS, Ebert PJ, Militerni R, Bravaccio C, Trillo S et al (2006). A genetic variant that disrupts MET transcription is associated with autism. Proc Natl Acad Sci USA 103: 16834-16839.

Capuron L, Miller AH (2011). Immune system to brain signaling: neuropsychopharmacological implications. Pharmacol Ther 130: 226-238.

Careaga M, Van de Water J, Ashwood P (2010). Immune dysfunction in autism: a pathway to treatment. Neurotherapeutics 7: 283-292.

Carneiro AM, Blakely RD (2006). Serotonin-, protein kinase C-, and Hic-5associated redistribution of the platelet serotonin transporter. J Biol Chem 281 : 24769-24780.

Carneiro AM, Cook EH, Murphy DL, Blakely RD (2008). Interactions between integrin alphallbbeta3 and the serotonin transporter regulate serotonin transport and platelet aggregation in mice and humans. J Clin Invest 118: 1544-1552.

Casanova MF, Buxhoeveden DP, Switala AE, Roy E (2002). Minicolumnar pathology in autism. Neurology 58: 428-432.

Cascio C, McGlone F, Folger S, Tannan V, Baranek G, Pelphrey KA et al (2008). Tactile perception in adults with autism: a multidimensional psychophysical study. J Autism Dev Disord 38: 127-137.

Chakrabarti S, Fombonne E (2005). Pervasive developmental disorders in preschool children: confirmation of high prevalence. Am J Psychiatry 162: 1133-1141.

Chanrion B, Mannoury la Cour C, Bertaso F, Lerner-Natoli M, Freissmuth M, Millan $\mathrm{MJ}$ et al (2007). Physical interaction between the serotonin transporter and neuronal nitric oxide synthase underlies reciprocal modulation of their activity. Proc Natl Acad Sci USA 104: 8119-8124.

Chen R, Jiao Y, Herskovits EH (2011). Structural MRI in autism spectrum disorder. Pediatr Res 69(5 Part 2): 63R-68R.

Cheslack-Postava K, Liu K, Bearman PS (2011). Closely spaced pregnancies are associated with increased odds of autism in California sibling births. Pediatrics 127: 246-253.

Chess S (1971). Autism in children with congenital rubella. J Autism Child Schizophr 1: 33-47. Early evidence of a prenatal infection that increases risk of autism.

Chez MG, Chang M, Krasne V, Coughlan C, Kominsky M, Schwartz A (2006). Frequency of epileptiform EEG abnormalities in a sequential screening of autistic patients with no known clinical epilepsy from 1996 to 2005. Epilepsy Behav 8: 267-271.

Christian SL, Brune CW, Sudi J, Kumar RA, Liu S, Karamohamed S et al (2008). Novel submicroscopic chromosomal abnormalities detected in autism spectrum disorder. Biol Psychiatry 63: 1111-1117.

Chugani DC, Muzik O, Behen M, Rothermel R, Janisse JJ, Lee J et al (1999). Developmental changes in brain serotonin synthesis capacity in autistic and nonautistic children. Ann Neurol 45: 287-295.

Cleary C, Linde JA, Hiscock KM, Hadas I, Belmaker RH, Agam G et al (2008). Antidepressive-like effects of rapamycin in animal models: Implications for mTOR inhibition as a new target for treatment of affective disorders. Brain Res Bull 76: 469-473.

Consortium ECTS (1993). Identification and characterization of the tuberous sclerosis gene on chromosome 16. Cell 75: 1305-1315.
Constantino JN, Majmudar P, Bottini A, Arvin M, Virkud Y, Simons P et al (2010a). Infant head growth in male siblings of children with and without autism spectrum disorders. J Neurodev Disord 2: 39-46.

Constantino JN, Todd RD (2003). Autistic traits in the general population: a twin study. Arch Gen Psychiatry 60: 524-530.

Constantino JN, Zhang Y, Frazier T, Abbacchi AM, Law P (2010b). Sibling recurrence and the genetic epidemiology of autism. Am J Psychiatry 167: 1349-1356.

Cook E, Arora R, Anderson G, Berry-Kravis E, Yan S-Y, Yeoh H et al (1993). Platelet serotonin studies in hyperserotonemic relatives of children with autistic disorder. Life Sci 52: 2005-2015.

Cook E, Lindgren V, Leventhal B, Courchesne R, Lincoln A, Shulman C et al (1997). Autism or atypical autism in maternally but not paternally derived proximal $15 q$ duplication. Am J Hum Genet 60: 928-934.

Cook Jr EH, Fletcher KE, Wainwright M, Marks N, Yan SY, Leventhal BL (1994). Primary structure of the human platelet serotonin 5-HT2A receptor: identify with frontal cortex serotonin 5-HT2A receptor. J Neurochem 63: 465-469.

Coskun MA, Varghese L, Reddoch S, Castillo EM, Pearson DA, Loveland KA et al (2009). How somatic cortical maps differ in autistic and typical brains. Neuroreport 20: 175-179.

Costenia AR, Lopes LV, de Mendonca A, Ribeiro JA (2001). A functional role for adenosine A3 receptors: modulation of synaptic plasticity in the rat hippocampus. Neurosci Lett 302: 53-57.

Courchesne E, Campbell K, Solso S (2011). Brain growth across the life span in autism: age-specific changes in anatomical pathology. Brain Res 1380: 138-145.

Courchesne E, Carper R, Akshoomoff N (2003). Evidence of brain overgrowth in the first year of life in autism. JAMA 290: 337-344. Demonstration of increased brain growth in early childhood in children who go on to have ASD.

Courchesne E, Karns CM, Davis HR, Ziccardi R, Carper RA, Tigue ZD et al (2001). Unusual brain growth patterns in early life in patients with autistic disorder: an MRI study. Neurology 57: 245-254.

Courchesne E, Muller RA, Saitoh O (1999). Brain weight in autism: normal in the majority of cases, megalencephalic in rare cases. Neurology 52: 1057-1059.

Courchesne E, Pierce K (2005). Why the frontal cortex in autism might be talking only to itself: local over-connectivity but long-distance disconnection. Curr Opin Neurobiol 15: 225-230.

Croen LA, Grether JK, Yoshida CK, Odouli R, Hendrick V (2011). Antidepressant use during pregnancy and childhood autism spectrum disorders. Arch Gen Psychiatry (e-pub ahead of print 4 Jully 2011).

Cross S, Kim SJ, Weiss LA, Delahanty RJ, Sutcliffe JS, Leventhal BL et al (2008). Molecular genetics of the platelet serotonin system in first-degree relatives of patients with autism. Neuropsychopharmacology 33: 353-360.

Dalton KM, Nacewicz BM, Johnstone T, Schaefer HS, Gernsbacher MA, Goldsmith $\mathrm{HH}$ et al (2005). Gaze fixation and the neural circuitry of face processing in autism. Nat Neurosci 8: 519-526.

Dawson G, Rogers S, Munson J, Smith M, Winter J, Greenson J et al (2010). Randomized, controlled trial of an intervention for toddlers with autism: the Early Start Denver Model. Pediatrics 125: e17-e23. Initial publication of a promising early intensive behavioral intervention for young children with ASD.

de Vrij FM, Levenga J, van der Linde HC, Koekkoek SK, De Zeeuw CI, Nelson DL et al (2008). Rescue of behavioral phenotype and neuronal protrusion morphology in Fmr1 KO mice. Neurobiol Dis 31: 127-132.

Di Martino A, Ross K, Uddin LQ, Sklar AB, Castellanos FX, Milham MP (2009). Functional brain correlates of social and nonsocial processes in autism spectrum disorders: an activation likelihood estimation meta-analysis. Biol Psychiatry 65: 63-74.

Dolen G, Osterweil E, Rao BS, Smith GB, Auerbach BD, Chattarii S et al (2007). Correction of fragile $X$ syndrome in mice. Neuron 56: 955-962. Demonstration that decreasing expression of the mGluR5 receptor gene leads to a reversal of several brain and behavioral phenotypes in mice lacking Fmrl.

Dunwiddle TV, Diao L, Kim HO, Jiang JL, Jacobson KA (1997). Activation of hippocampal adenosine $A 3$ receptors produces a desensitization of $A 1$ receptormediated responses in rat hippocampus. J Neurosci 17: 607-614.

Durand CM, Betancur C, Boeckers TM, Bockmann J, Chaste P, Fauchereau F et al (2007). Mutations in the gene encoding the synaptic scaffolding protein SHANK3 are associated with autism spectrum disorders. Nat Genet 39: $25-27$.

Durkin MS, Maenner MJ, Newschaffer CJ, Lee LC, Cunniff CM, Daniels JL et al (2008). Advanced parental age and the risk of autism spectrum disorder. Am J Epidemiol 168: 1268-1276.

Duszak RS (2009). Congenital rubella syndrome-major review. Optometry 80: $36-43$. 
Eberhart DE, Malter HE, Feng Y, Warren ST (1996). The fragile X mental retardation protein is a ribonucleoprotein containing both nuclear localization and nuclear export signals. Hum Mol Genet 5: 1083-1091.

Edwards DJ, Chugani DC, Chugani HT, Chehab J, Malian M, Aranda JV (2006). Pharmacokinetics of buspirone in autistic children. J Clin Pharmacol 46: 508-514.

Ehninger D, Han S, Shilyansky C, Zhou Y, Li W, Kwiatkowski DJ et al (2008a). Reversal of learning deficits in a Tsc2+/- mouse model of tuberous sclerosis. Nat Med 14: 843-848. Demonstration that rapamycin blockade of mTor signaling ameliorates both synaptic and behavioral deficits in mice lacking Tsc2.

Ehninger D, Li W, Fox K, Stryker MP, Silva AJ (2008b). Reversing neurodevelopmental disorders in adults. Neuron 60: 950-960. Important review of opportunities to alter the consequences of developmental disorders in adulthood.

Elder LM, Dawson G, Toth K, Fein D, Munson J (2008). Head circumference as an early predictor of autism symptoms in younger siblings of children with autism spectrum disorder. J Autism Dev Disord 38: 1104-1111.

Erickson CA, Stigler KA, Corkins MR, Posey DJ, Fitzgerald JF, McDougle CJ (2005). Gastrointestinal factors in autistic disorder: a critical review. J Autism Dev Disord 35: 713-727.

Faraj BA, Olkowski ZL, Jackson RT (1994). Expression of a high-affinity serotonin transporter in human lymphocytes. Int J Immunopharmacol 16: 561-567.

Fatemi SH, Reutiman TJ, Folsom TD, Thuras PD (2009). GABA(A) receptor downregulation in brains of subjects with autism. J Autism Dev Disord 39: 223-230.

Folstein S, Rutter M (1977). Infantile autism: A genetic study of 21 twin pairs. J Child Psychol, Psychiatry 18: 297-321. First twin study in ASD shows increased rate of concordance in monozygotic versus dizygotic twins.

Fombonne E (2003). Epidemiological surveys of autism and other pervasive developmental disorders: an update. J Autism Dev Disord 33: 365-382.

Foss-Feig JH, Kwakye LD, Cascio CJ, Burnette CP, Kadivar H, Stone WL et al (2010). An extended multisensory temporal binding window in autism spectrum disorders. Exp Brain Res 203: 381-389.

Frazier TW, Hardan AY (2009). A meta-analysis of the corpus callosum in autism. Biol Psychiatry 66: 935-941.

Frye RE, Rossignol DA (2011). Mitochondrial dysfunction can connect the diverse medical symptoms associated with autism spectrum disorders. Pediatr Res 69(5 Part 2): 41R-47R.

Gardener H, Spiegelman D, Buka SL (2009). Prenatal risk factors for autism: comprehensive meta-analysis. Br J Psychiatry 195: 7-14.

Georgiades S, Szatmari P, Zwaigenbaum L, Duku E, Bryson S, Roberts W et al (2007). Structure of the autism symptom phenotype: a proposed multidimensional model. J Am Acad Child Adolesc Psychiatry 46: 188-196.

Gharani N, Benayed R, Mancuso V, Brzustowicz LM, Millonig JH (2004). Association of the homeobox transcription factor, ENGRAILED 2, 3, with autism spectrum disorder. Mol Psychiatry 9: 474-484.

Giulivi C, Zhang YF, Omanska-Klusek A, Ross-Inta C, Wong S, Hertz-Picciotto I et al (2010). Mitochondrial dysfunction in autism. JAMA 304: 2389-2396.

Glessner JT, Wang K, Cai G, Korvatska O, Kim CE, Wood S et al (2009). Autism genome-wide copy number variation reveals ubiquitin and neuronal genes. Nature 459: 569-573.

Goffin A, Hoefsloot L, Bosgoed E, Swillen A, Fryns J-P (2001). PTEN mutation in a family with Cowden syndrome and autism. Am J Med Genet 105: 521-524.

Goldberg J, Anderson GM, Zwaigenbaum L, Hall GB, Nahmias C, Thompson A et al (2009). Cortical serotonin type-2 receptor density in parents of children with autism spectrum disorders. J Autism Dev Disord 39: 97-104.

Gordon C, State R, Nelson J, Hamburger S, Rapoport J (1993). A double-blind comparison of clomipramine, desipramine, and placebo in the treatment of autistic disorder. Arch Gen Psychiatry 50: 441-447.

Gottesman II, Gould TD (2003). The endophenotype concept in psychiatry: etymology and strategic intentions. Am J Psychiatry 160: 636-645.

Gruss M, Braun K (2001). Alterations of amino acids and monoamine metabolism in male Fmr1 knockout mice: a putative animal model of the human fragile $\mathrm{X}$ mental retardation syndrome. Neural Plast 8: 285-298.

Guy J, Gan J, Selfridge J, Cobb S, Bird A (2007). Reversal of neurological defects in a mouse model of Rett syndrome. Science 315: 1143-1147.

Haas HL, Selbach O (2000). Functions of neuronal adenosine receptors. Naunyn Schmiedeberg's Arch Pharmacol 362: 375-381.

Hagerman RJ, Berry-Kravis E, Kaufmann WE, Ono MY, Tartaglia N, Lachiewicz A et al (2009). Advances in the treatment of fragile $X$ syndrome. Pediatrics 123: 378-390

Hall SS, Lightbody AA, Hirt M, Rezvani A, Reiss AL (2010). Autism in fragile $X$ syndrome: a category mistake? J Am Acad Child Adolesc Psychiatry 49: 921-933.
Hamdan FF, Daoud H, Piton A, Gauthier J, Dobrzeniecka S, Krebs MO et al (2011). De novo SYNGAP1 mutations in nonsyndromic intellectual disability and autism. Biol Psychiatry 69: 898-901.

Hamdan FF, Gauthier J, Spiegelman D, Noreau A, Yang Y, Pellerin S et al (2009). Mutations in SYNGAP1 in autosomal nonsyndromic mental retardation. N Engl J Med 360: 599-605.

Hanley HG, Stahl SM, Freedman DX (1977). Hyperserotonemia and amine metabolites in autistic and retarded children. Arch Gen Psychiatry 34: 521-531.

Happe F, Frith U (2006). The weak coherence account: detail-focused cognitive style in autism spectrum disorders. J Autism Dev Disord 36: 5-25.

Harris SW, HessI D, Goodlin-Jones B, Ferranti J, Bacalman S, Barbato I et al (2008). Autism profiles of males with fragile $X$ syndrome. Am J Ment Retard 113: 427-438.

Hasko G, Linden J, Cronstein B, Pacher P (2008). Adenosine receptors: therapeutic aspects for inflammatory and immune diseases. Nat Rev Drug Discov 7: 759-770.

Hazlett HC, Poe M, Gerig G, Smith RG, Provenzale J, Ross A et al (2005). Magnetic resonance imaging and head circumference study of brain size in autism: birth through age 2 years. Arch Gen Psychiatry 62: 1366-1376.

Haznedar MM, Buchsbaum MS, Hazlett EA, LiCalzi EM, Cartwright C, Hollander E (2006). Volumetric analysis and three-dimensional glucose metabolic mapping of the striatum and thalamus in patients with autism spectrum disorders. Am J Psychiatry 163: 1252-1263.

Hessl D, Tassone F, Cordeiro L, Koldewyn K, McCormick C, Green C et al (2008). Brief report: aggression and stereotypic behavior in males with fragile $X$ syndrome - moderating secondary genes in a 'single gene' disorder. J Autism Dev Disord 38: 184-189.

Heulens I, Kooy F (2011). Fragile X syndrome: from gene discovery to therapy. Front Biosci 16: 1211-1232.

Hill EL (2004). Executive dysfunction in autism. Trends Cogn Sci 8: 26-32.

Hofstetter HH, Mossner R, Lesch KP, Linker RA, Toyka KV, Gold R (2005). Absence of reuptake of serotonin influences susceptibility to clinical autoimmune disease and neuroantigen-specific interferon-gamma production in mouse EAE. Clin Exp Immunol 142: 39-44.

Hollander E, Phillips A, Chaplin W, Zagursky K, Novotny S, Wasserman S et al (2005). A placebo controlled crossover trial of liquid fluoxetine on repetitive behaviors in childhood and adolescent autism. Neuropsychopharmacology 30: 582-589.

Hrdlicka M, Komarek V, Propper L, Kulisek R, Zumrova A, Faladova L et al (2004). Not EEG abnormalities but epilepsy is associated with autistic regression and mental functioning in childhood autism. Eur Child Adolesc Psychiatry 13: 209-213.

Huber KM, Gallagher SM, Warren ST, Bear MF (2002). Altered synaptic plasticity in a mouse model of fragile $X$ mental retardation. Proc Natl Acad Sci USA 99: 7746-7750.

Hultman CM, Sandin S, Levine SZ, Lichtenstein P, Reichenberg A (2010). Advancing paternal age and risk of autism: new evidence from a populationbased study and a meta-analysis of epidemiological studies. Mol Psychiatry (e-pub ahead of print 3 November 2010).

Ibrahim SH, Voigt RG, Katusic SK, Weaver AL, Barbaresi WJ (2009). Incidence of gastrointestinal symptoms in children with autism: a population-based study. Pediatrics 124: 680-686.

International Molecular Genetic Study of Autism Consortium (2001). A genome wide screen for autism: strong evidence for linkage to chromosomes $2 \mathrm{q}, 7 \mathrm{q}$ and $16 \mathrm{p}$. Am J Hum Genet 69: 570-581.

Jacob S, Landeros-Weisenberger A, Leckman JF (2009). Autism spectrum and obsessive-compulsive disorders: OC behaviors, phenotypes and genetics. Autism Res 2: 293-311.

Jacquemont S, Curie A, des Portes V, Torrioli MG, Berry-Kravis E, Hagerman RJ et al (2011). Epigenetic modification of the FMR1 gene in fragile $X$ syndrome is associated with differential response to the mGluR5 antagonist AFQ056. Sci Transl Med 3: 64ra61. First randomized controlled trial of an mGluR5 antagonist for treatment of Fragile $X$ Syndrome shows equivocal results in the overall population but improvements in individuals with full methylation of FMR1

Jamain S, Quach H, Betancur C, Rastam M, Colineaux C, Gillberg IC et al (2003). Mutations of the X-linked genes encoding neuroligins NLGN3 and NLGN4 are associated with autism. Nat Genet 34: 27-29.

Jorde L, Hasstedt S, Ritvo E, Mason-Brothers A, Freeman B, Pingree C et al (1991). Complex segregation analysis of autism. Am J Hum Genet 49: 932-938.

Kanner L (1943). Autistic disturbances of affective contact. Nerv Child 2: 217-250. First description of autism as a clinical entity that included social communication deficits and repetitive behavior. 
Kilic F, Murphy D, Rudick G (2003). A human serotonin transporter mutation causes constitutive activation of transport activity. Mol Pharmacol 64: 440-446.

Kim HG, Kishikawa S, Higgins AW, Seong IS, Donovan DJ, Shen Y et al (2008). Disruption of neurexin 1 associated with autism spectrum disorder. Am J Hum Genet 82: 199-207.

Kim HL, Donnelly JH, Tournay AE, Book TM, Filipek P (2006). Absence of seizures despite high prevalence of epileptiform EEG abnormalities in children with autism monitored in a tertiary care center. Epilepsia 47: 394-398.

Kim JE, Lyoo IK, Estes AM, Renshaw PF, Shaw DW, Friedman SD et al (2010). Laterobasal amygdalar enlargement in 6- to 7-year-old children with autism spectrum disorder. Arch Gen Psychiatry 67: 1187-1197.

King BH, Hollander E, Sikich L, McCracken JT, Scahill L, Bregman JD et al (2009a). Lack of efficacy of citalopram in children with autism spectrum disorders and high levels of repetitive behavior: citalopram ineffective in children with autism. Arch Gen Psychiatry 66: 583-590. Largest study of a serotonin reuptake inhibitor in ASD showed no benefit for repetitive behavior and only a modest effect on irritability.

King MD, Fountain C, Dakhlallah D, Bearman PS (2009b). Estimated autism risk and older reproductive age. Am J Public Health 99: 1673-1679.

Kingwood K (2011). Psychiatric disorders: the stresses of womanhood. Nature Rev Neurosci 12: 185.

Kleinhans NM, Johnson LC, Richards T, Mahurin R, Greenson J, Dawson G et al (2009). Reduced neural habituation in the amygdala and social impairments in autism spectrum disorders. Am J Psychiatry 166: 467-475.

Kremer EJ, Pritchard M, Lynch M, Yu S, Holman K, Baker E et al (1991). Mapping of DNA instability at the fragile $X$ to a trinucleotide repeat sequence $p(C C G) n$. Science 252: 1711-1714.

Kumar RA, KaraMohamed S, Sudi J, Conrad DF, Brune C, Badner JA et al (2008). Recurrent 16p11.2 microdeletions in autism. Hum Mol Genet 17: 628-638.

Kwakye LD, Foss-Feig JH, Cascio CJ, Stone WL, Wallace MT (2011). Altered auditory and multisensory temporal processing in autism spectrum disorders. Front Integr Neurosci 4: 129.

Kwon CH, Luikart BW, Powell CM, Zhou J, Matheny SA, Zhang W et al (2006). Pten regulates neuronal arborization and social interaction in mice. Neuron 50 377-388.

Lam KS, Bodfish JW, Piven J (2008). Evidence for three subtypes of repetitive behavior in autism that differ in familiality and association with other symptoms. J Child Psychol Psychiatry 49: 1193-1200.

Langen M, Durston S, Staal WG, Palmen SJ, van Engeland $H$ (2007). Caudate nucleus is enlarged in high-functioning medication-naive subjects with autism. Biol Psychiatry 62: 262-266.

Langen M, Schnack HG, Nederveen H, Bos D, Lahuis BE, de Jonge MV et al (2009). Changes in the developmental trajectories of striatum in autism. Biol Psychiatry 66: 327-333.

Lesch KP, Wolozin BL, Murphy DL, Riederer P (1993). Primary structure of the human platelet serotonin uptake site: identity with the brain serotonin transporter. J Neurochemi 60: 2319-2322.

Levenga J, Hayashi S, de Vrij FM, Koekkoek SK, van der Linde HC, Nieuwenhuizen I et al (2011). AFQ056, a new mGluR5 antagonist for treatment of fragile $X$ syndrome. Neurobiol Dis 42: 311-317.

Levitt P, Campbell DB (2009). The genetic and neurobiologic compass points toward common signaling dysfunctions in autism spectrum disorders. J Clin Invest 119: 747-754.

Leyfer OT, Folstein SE, Bacalman S, Davis NO, Dinh E, Morgan J et al (2006). Comorbid psychiatric disorders in children with autism: interview development and rates of disorders. J Autism Dev Disord 36: 849-861.

Li N, Lee B, Liu RJ, Banasr M, Dwyer JM, Iwata M et al (2010). mTOR-dependent synapse formation underlies the rapid antidepressant effects of NMDA antagonists. Science 329: 959-964.

Li W, Cui Y, Kushner SA, Brown RA, Jentsch JD, Frankland PW et al (2005). The HMG-COA reductase inhibitor lovastatin reverses the learning and attention deficits in a mouse model of neurofibromatosis type 1. Curr Biol 15: 1961-1967.

Lichtenstein P, Carlstrom E, Rastam M, Gillberg C, Anckarsater H (2010). The genetics of autism spectrum disorders and related neuropsychiatric disorders in childhood. Am J Psychiatry 167: 1357-1363.

Limperopoulos C, Bassan H, Sullivan NR, Soul JS, Robertson Jr RL, Moore M et al (2008). Positive screening for autism in ex-preterm infants: prevalence and risk factors. Pediatrics 121: 758-765

Loesch DZ, Bui QM, Dissanayake C, Clifford S, Gould E, Bulhak-Paterson D et al (2007). Molecular and cognitive predictors of the continuum of autistic behaviours in fragile X. Neurosci Biobehav Rev 31: 315-326.

Macek TA, Schaffhauser H, Conn PJ (1998). Protein kinase C and A3 adenosine receptor activation inhibit presynaptic metabotropic glutamate receptor (mGluR) function and uncouple mGluRs from GTP-binding proteins. J Neurosci 18: 6138-6146.
Marco EJ, Hinkley LB, Hill SS, Nagarajan SS (2011). Sensory processing in autism: a review of neurophysiologic findings. Pediatr Res 69(5 Part 2): 48R-54R.

Marcus RN, Owen R, Kamen L, Manos G, McQuade RD, Carson WH et al (2009). A placebo-controlled, fixed-dose study of aripiprazole in children and adolescents with irritability associated with autistic disorder. I Am Acad Child Adolesc Psychiatry 48: 1110-1119.

Mattila ML, Hurtig T, Haapsamo H, Jussila K, Kuusikko-Gauffin S, Kielinen M et al (2010). Comorbid psychiatric disorders associated with Asperger syndrome/ high-functioning autism: a community- and clinic-based study. J Autism Dev Disord 40: 1080-1093.

McBride PA, Anderson GM, Hertzig ME, Sweeney JA, Kream J, Cohen DJ et al (1989). Serotonergic responsivity in male young adults with autistic disorder. Arch Gen Psychiatry 46: 205-212.

McCauley JL, Olson LM, Dowd M, Amin T, Steele A, Blakely RD et al (2004). Linkage and association analysis at the serotonin transporter (SLC6A4) locus in a rigid-compulsive subset of autism. Am J Med Genet B Neuropsychiatr Genet 127: 104-112.

McCracken JT, McGough J, Shah B, Cronin P, Hong D, Aman MG et al (2002). Risperidone in children with autism and serious behavioral problems. $N$ Engl J Med 347: 314-321. Initial study that supported risperidone as the first medication specifically approved by the Food and Drug Administration in children with ASD (for the treatment of irritability/agitation).

McDougle C, Naylor S, Cohen D, Volkmar F, Heninger G, Price L (1996). A doubleblind, placebo-controlled study of fluvoxamine in adults with autistic disorder. Arch Gen Psychiatry 53: 1001-1008.

McDougle CJ, Naylor ST, Goodman WK, Volkmar FR, Cohen DJ, Price LH (1993). Acute tryptophan depletion in autistic disorder: a controlled case study. Biol Psychiatry 33: 547-550. Important support for altered 5-HT signaling in vivo as an underlying trait of autism.

McDougle CJ, Scahill L, Aman MG, McCracken JT, Tierney E, Davies M et al (2005). Risperidone for the core symptom domains of autism: results from the study by the autism network of the research units on pediatric psychopharmacology. Am J Psychiatry 162: 1142-1148.

McPheeters ML, Warren Z, Sathe N, Bruzek JL, Krishnaswami S, Jerome RN et al (2011). A systematic review of medical treatments for children with autism spectrum disorders. Pediatrics 127: e1312-e1321.

Meredith EJ, Holder MJ, Chamba A, Challa A, Drake Lee A, Bunce CM et al (2005). The serotonin transporter (SLC6A4) is present in B-cell clones of diverse malignant origin: probing a potential antitumor target for psychotropics. FASEB J 19: $1187-1189$

Mosconi MW, Cody-Hazlett H, Poe MD, Gerig G, Gimpel-Smith R, Piven J (2009). Longitudinal study of amygdala volume and joint attention in 2- to 4-year-old children with autism. Arch Gen Psychiatry 66: 509-516.

Mulder EJ, Anderson GM, Kema IP, de Bildt A, van Lang ND, den Boer JA et al (2004). Platelet serotonin levels in pervasive developmental disorders and mental retardation: diagnostic group differences, within-group distribution, and behavioral correlates. J Am Acad Child Adolesc Psychiatry 43: 491-499.

Munson J, Dawson G, Sterling L, Beauchaine T, Zhou A, Elizabeth K et al (2008). Evidence for latent classes of IQ in young children with autism spectrum disorder. Am J Ment Retard 113: 439-452.

Murphy DG, Daly E, Schmitz N, Toal F, Murphy K, Curran S et al (2006). Cortical serotonin 5-HT2A receptor binding and social communication in adults with Asperger's syndrome: an in vivo SPECT study. Am J Psychiatry 163: 934-936. Shows that brain $5-\mathrm{HT}_{2 \mathrm{~A}}$ receptor binding is decreased in ASD in parallel with previously described decreases in platelet $5-\mathrm{HT}_{2 \mathrm{~A}}$ receptor binding.

Nacewicz BM, Dalton KM, Johnstone T, Long MT, McAuliff EM, Oakes TR et al (2006). Amygdala volume and nonverbal social impairment in adolescent and adult males with autism. Arch Gen Psychiatry 63: 1417-1428.

Nakamura K, Sekine Y, Ouchi Y, Tsujii M, Yoshikawa E, Futatsubashi M et al (2010). Brain serotonin and dopamine transporter bindings in adults with high functioning autism. Arch Gen Psychiatry 67: 59-68.

Network RUoPPA (2005). Randomized, controlled, crossover trial of methylphenidate in pervasive developmental disorders with hyperactivity. Arch Gen Psychiatry 62: 1266-1274.

Noor A, Whibley A, Marshall CR, Gianakopoulos PJ, Piton A, Carson AR et al (2010). Disruption at the PTCHD1 locus on Xp22.11 in autism spectrum disorder and intellectual disability. Sci Trans/ Med 2: 49 ra68.

Numis AL, Major P, Montenegro MA, Muzykewicz DA, Pulsifer MB, Thiele EA (2011). Identification of risk factors for autism spectrum disorders in tuberous sclerosis complex. Neurology 76: 981-987.

Oblak AL, Gibbs T, Blatt GJ (2011). Reduced GABAA receptors and benzodiazepine binding sites in the posterior cingulate cortex and fusiform gyrus in autism. Brain Res 1380: 218-228. 
Oliveira G, Diogo L, Grazina M, Garcia P, Ataide A, Marques C et al (2005). Mitochondrial dysfunction in autism spectrum disorders: a population-based study. Dev Med Child Neurol 47: 185-189.

Ozaki N, Goldman D, Kaye W, Plotnikov K, Greenberg B, Rudnick G et al (2003). A missense mutation in the serotonin transporter is associated with a complex neuropsychiatric phenotype. Mol Psychiatry 8: 933-936. Identification of a SERT coding variant in two families segregating OCD, ASD, social phobia, and other disorders. Same site later identified with functional variation in multiplex ASD subjects by Sutcliffe et al (2005).

Ozonoff S, losif AM, Baguio F, Cook IC, Hill MM, Hutman T et al (2010). A prospective study of the emergence of early behavioral signs of autism. J Am Acad Child Adolesc Psychiatry 49: 256-266. e251-252.

Page DT, Kuti OJ, Prestia C, Sur M (2009). Haploinsufficiency for Pten and serotonin transporter cooperatively influences brain size and social behavior. Proc Natl Acad Sci USA 106: 1989-1994. Evidence that 5-HT and PTEN-controlled signaling collaborate, linking 5-HT actions to mTOR signaling.

Panerai S, Zingale M, Trubia G, Finocchiaro M, Zuccarello R, Ferri R et al (2009). Special education versus inclusive education: the role of the TEACCH program. J Autism Dev Disord 39: 874-882.

Parikh MS, Kolevzon A, Hollander E (2008). Psychopharmacology of aggression in children and adolescents with autism: a critical review of efficacy and tolerability. $J$ Child Adolesc Psychopharmacol 18: 157-178.

Patterson PH (2011). Modeling autistic features in animals. Pediatr Res 69(5 Part 2): 34R-40R.

Penagarikano O, Mulle JG, Warren ST (2007). The pathophysiology of fragile $X$ syndrome. Annu Rev Genomics Hum Genet 8: 109-129.

Pinto D, Pagnamenta AT, Klei L, Anney R, Merico D, Regan R et al (2010). Functional impact of global rare copy number variation in autism spectrum disorders. Nature 466: 368-372.

Piton A, Michaud JL, Peng H, Aradhya S, Gauthier J, Mottron L et al (2008). Mutations in the calcium-related gene IL1RAPL1 are associated with autism. Hum Mol Genet 17: 3965-3974.

Prasad HC, Steiner JA, Sutcliffe JS, Blakely RD (2009). Enhanced activity of human serotonin transporter variants associated with autism. Philos Trans $R$ Soc Lond $B$ Biol Sci 364: 163-173.

Prasad HC, Zhu CB, McCauley JL, Samuvel DJ, Ramamoorthy S, Shelton RC et al (2005). Human serotonin transporter variants display altered sensitivity to protein kinase $\mathrm{G}$ and p38 mitogen-activated protein kinase. Proc Natl Acad Sci USA 102: 11545-11550.

Prasad PD, Hoffmans BJ, Moe AJ, Smith CH, Leibach FH, Ganapathy V (1996). Functional expression of the plasma membrane serotonin transporter but not the vesicular monoamine transporter in human placental trophoblasts and choriocarcinoma cells. Placenta 17: 201-207.

Quick MW (2003). Regulating the conducting states of a mammalian serotonin transporter. Neuron 40: 537-549.

Ramamoorthy S, Bauman AL, Moore KR, Han H, Yang-Feng T, Chang AS et al (1993). Antidepressant- and cocaine-sensitive human serotonin transporter: molecular cloning, expression, and chromosomal localization. Proc Natl Acad Sci USA 90: 2542-2546.

Ramocki MB, Zoghbi HY (2008). Failure of neuronal homeostasis results in common neuropsychiatric phenotypes. Nature 455: 912-918.

Redcay E, Courchesne E (2005). When is the brain enlarged in autism? A metaanalysis of all brain size reports. Biol Psychiatry 58: 1-9.

Ressler KJ, Mercer KB, Bradley B, Jovanovic T, Mahan A, Kerley K et al (2011). Post-traumatic stress disorder is associated with PACAP and the PAC1 receptor. Nature 470: 492-497.

Richler J, Bishop SL, Kleinke JR, Lord C (2007). Restricted and repetitive behaviors in young children with autism spectrum disorders. J Autism Dev Disord 37: 73-85.

Richler J, Huerta M, Bishop SL, Lord C (2010). Developmental trajectories of restricted and repetitive behaviors and interests in children with autism spectrum disorders. Dev Psychopathol 22: 55-69.

Ritvo E, Jorde L, Mason-Brothers A, Freeman B, Pingree C, Jones M et al (1989). The UCLA-University of Utah epidemiologic survey of autism: recurrence risk estimates and genetic counseling. Am J Psychiatry 146: 1032-1036.

Rivkees SA, Thevananther S, Hao H (2000). Are A3 adenosine receptors expressed in the brain? Neuroreport 11: 1025-1030.

Rosenberg RE, Law JK, Yenokyan G, McGready J, Kaufmann WE, Law PA (2009). Characteristics and concordance of autism spectrum disorders among 277 twin pairs. Arch Pediatr Adolesc Med 163: 907-914.

Rubenstein JL, Merzenich MM (2003). Model of autism: increased ratio of excitation/inhibition in key neural systems. Genes Brain Behav 2: 255-267.

Salichon N, Gaspar P, Upton AL, Picaud S, Hanoun N, Hamon M et al (2001). Excessive activation of serotonin $(5-\mathrm{HT}) 1 \mathrm{~B}$ receptors disrupts the formation of sensory maps in monoamine oxidase a and 5-ht transporter knockout mice. J Neurosci 21: 884-896.

Samuvel DJ, Jayanthi LD, Bhat NR, Ramamoorthy S (2005). A role for p38 mitogenactivated protein kinase in the regulation of the serotonin transporter: evidence for distinct cellular mechanisms involved in transporter surface expression. J Neurosci 25: 29-41.

Schain RJ, Freedman DX (1961). Studies on 5-hydroxyindole metabolism in autistic and other mentally retarded children. J Pediatrics 58: 315-320. Early evidence of increased whole blood serotonin levels in individuals with ASD. Replicated in subsequent studies and shown to be specific to ASD.

Schendel D, Bhasin TK (2008). Birth weight and gestational age characteristics of children with autism, including a comparison with other developmental disabilities. Pediatrics 121: 1155-1164.

Schieve LA, Baio J, Rice CE, Durkin M, Kirby RS, Drews-Botsch C et al (2010). Risk for cognitive deficit in a population-based sample of US children with autism spectrum disorders: variation by perinatal health factors. Disabil Health $J$ 3: 202-212.

Schumann CM, Barnes CC, Lord C, Courchesne E (2009). Amygdala enlargement in toddlers with autism related to severity of social and communication impairments. Biol Psychiatry 66: 942-949.

Schumann CM, Bloss CS, Barnes CC, Wideman GM, Carper RA, Akshoomoff N et al (2010). Longitudinal magnetic resonance imaging study of cortical development through early childhood in autism. J Neurosci 30: 4419-4427.

Sears LL, Vest C, Mohamed S, Bailey J, Ranson BJ, Piven J (1999). An MRI study of the basal ganglia in autism. Prog Neuropsychopharmacol Biol Psychiatry 23: 613-624.

Sharma A, Hoeffer CA, Takayusa Y, Miyawaki T, McBride SM, Klann E et al (2010). Dysregulation of mTOR signaling in fragile X syndrome. J Neurosci 30: 694-702.

Shukla DK, Keehn B, Lincoln AJ, Muller RA (2010). White matter compromise of callosal and subcortical fiber tracts in children with autism spectrum disorder: a diffusion tensor imaging study. J Am Acad Child Adolesc Psychiatry 49: 1269-1278, 1278.e1261-1262.

Shumway S, Thurm A, Swedo SE, Deprey L, Barnett LA, Amaral DG et al (2011). Brief report: symptom onset patterns and functional outcomes in young children with autism spectrum disorders. J Autism Dev Disord (e-pub ahead of print 1 March 2011)

Silverman JL, Tolu SS, Barkan CL, Crawley JN (2010). Repetitive self-grooming behavior in the BTBR mouse model of autism is blocked by the mGluR5 antagonist MPEP. Neuropsychopharmacology 35: 976-989.

Simonoff E, Pickles A, Charman T, Chandler S, Loucas T, Baird G (2008). Psychiatric disorders in children with autism spectrum disorders: prevalence, comorbidity, and associated factors in a population-derived sample. J Am Acad Child Adolesc Psychiatry 47: 921-929.

Skuse D, James R, Bishop D, Coppin B, Dalton P, Aamodt-Leeper G et al (1997). Evidence from Turner's syndrome of an imprinted X-linked locus affecting cognitive function. Nature 387: 705-708. Demonstration of worsened social function in girls with Turner syndrome who receive their $\mathrm{X}$ chromosome from their mother, paralleling the inheritance of the $X$ chromosome in males. This suggests genetic imprinting as one potential factor underlying increased ASD susceptibility in males.

Skuse DH, Mandy WP, Scourfield J (2005). Measuring autistic traits: heritability, reliability and validity of the Social and Communication Disorders Checklist. $\mathrm{Br} \mathrm{J}$ Psychiatry 187: 568-572.

Smith CJ, Lang CM, Kryzak L, Reichenberg A, Hollander E, Silverman JM (2009). Familial associations of intense preoccupations, an empirical factor of the restricted, repetitive behaviors and interests domain of autism. J Child Psychol Psychiatry 50: 982-990.

Smith T, Groen AD, Wynn JW (2000). Randomized trial of intensive early intervention for children with pervasive developmental disorder. Am J Ment Retard 105: 269-285. Controlled trial supporting the benefits of early intensive behavioral intervention for some children with ASD.

Soll C, Jang JH, Reiner MO, Moritz W, Wild PJ, Graph R et al (2010). Serotonin promotes tumor growth in human hepatocellular cancer. Hepatology 51: 1244-1254.

Stanfield AC, Mclntosh AM, Spencer MD, Philip R, Gaur S, Lawrie SM (2008). Towards a neuroanatomy of autism: a systematic review and meta-analysis of structural magnetic resonance imaging studies. Eur Psychiatry 23: 289-299.

State MW (2011). The genetics of child psychiatric disorders: focus on autism and Tourette syndrome. Neuron 68: 254-269.

Steiner JA, Carneiro AM, Wright J, Matthies HJ, Prasad HC, Nicki CK et al (2009). cGMP-dependent protein kinase lalpha associates with the antidepressantsensitive serotonin transporter and dictates rapid modulation of serotonin uptake. Mol Brain 2: 26. 
Stone JL, Merriman B, Cantor RM, Yonan AL, Gilliam TC, Geschwind DH et al (2004). Evidence for sex-specific risk alleles in autism spectrum disorder. Am J Hum Genet 75: 1117-1123.

Stromland K, Nordin V, Miller M, Akerstrom B, Gillberg C (1994). Autism in thalidomide embryopathy: a population study. Dev Med Child Neurol 36: 351-356.

Su T, Fan HX, Jiang T, Sun WW, Den WY, Gao MM et al (2011). Early continuous inhibition of group $1 \mathrm{mGlu}$ signaling partially rescues dendritic spine abnormalities in the Fmr1 knockout mouse model for fragile $\mathrm{X}$ syndrome. Psychopharmacology (Berl) 215: 291-300.

Sudhof TC (2008). Neuroligins and neurexins link synaptic function to cognitive disease. Nature 455: 903-911.

Sutcliffe JS, Delahanty RJ, Prasad HC, McCauley JL, Han Q, Jiang L et al (2005). Allelic heterogeneity at the serotonin transporter locus (SLC6A4) confers susceptibility to autism and rigid-compulsive behaviors. Am J Hum Genet 77: 265-279. Identification of rare functional variants of the serotonin transporter in families with evidence of linkage on chromosome 17q.

Suvrathan A, Hoeffer CA, Wong H, Klann E, Chattarji S (2010). Characterization and reversal of synaptic defects in the amygdala in a mouse model of fragile $X$ syndrome. Proc Natl Acad Sci USA 107: 11591-11596.

Tadevosyan-Leyfer O, Dowd M, Mankoski R, Winklosky B, Putnam S, McGrath L et al (2003). A principal components analysis of the Autism Diagnostic Interview-Revised. J Am Acad Child Adolesc Psychiatry 42: 864-872.

Taliani S, Pugliese I, Bellandi M, La Motta C, Da Settimo F (2010). A3 receptor ligands: past, present and future trends. Curr Top Med Chem 10: 942-975.

Tommerdahl M, Tannan V, Cascio CJ, Baranek GT, Whitsel BL (2007). Vibrotactile adaptation fails to enhance spatial localization in adults with autism. Brain Res 1154: 116-123.

Tropea D, Giacometti E, Wilson NR, Beard C, McCurry C, Fu DD et al (2009). Partial reversal of Rett syndrome-like symptoms in MeCP2 mutant mice. Proc Natl Acad Sci USA 106: 2029-2034.

van Slegtenhorst M, de Hoogt R, Hermans C, Nellist M, Janssen B, Verhoef S et al (1997). Identification of the tuberous sclerosis gene TSC1 on chromosome 9q34. Science 277: 805-808.

van Woerden GM, Harris KD, Hojjati MR, Gustin RM, Qu S, de Avila Freire R et al (2007). Rescue of neurological deficits in a mouse model for Angelman syndrome by reduction of alphaCaMKII inhibitory phosphorylation. Nat Neurosci 10: 280-282.

Volkmar F, Cook Jr E, Pomeroy J, Realmuto G, Tanguay P (1999). Summary of the practice parameters for the assessment and treatment of children, adolescents, and adults with autism and other pervasive developmental disorders. J Am Acad Child Adolesc Psychiatry 38: 1611-1616.

Wang $\mathrm{K}$, Zhang H, Ma D, Bucan M, Glessner JT, Abrahams BS et al (2009). Common genetic variants on 5p14.1 associate with autism spectrum disorders. Nature 459: 528-533.

Wang LW, Tancredi DJ, Thomas DW (2011). The prevalence of gastrointestinal problems in children across the United States with autism spectrum disorders from families with multiple affected members. J Dev Behav Pediatr 32: 351-360.

Warren Z, McPheeters ML, Sathe N, Foss-Feig JH, Glasser A, VeenstraVanderweele $J$ (2011). A systematic review of early intensive intervention for autism spectrum disorders. Pediatrics 127: e1303-e1311.

Wassink TH, Hazlett HC, Epping EA, Arndt S, Dager SR, Schellenberg GD et al (2007). Cerebral cortical gray matter overgrowth and functional variation of the serotonin transporter gene in autism. Arch Gen Psychiatry 64: 709-717. Identification of association between serotonin transporter genotype and brain overgrowth in children with ASD.

Waterhouse L, Morris R, Allen D, Dunn M, Fein D, Feinstein C et al (1996). Diagnosis and classification in autism. J Autism Dev Disord 26: 59-86.

Weiss LA (2009). Autism genetics: emerging data from genome-wide copynumber and single nucleotide polymorphism scans. Expert Rev Mol Diagn 9: 795-803.
Weiss LA, Abney M, Cook Jr EH, Ober C (2005). Sex-specific genetic architecture of whole blood serotonin levels. Am J Hum Genet 76: 33-41.

Weiss LA, Arking DE, Daly MJ, Chakravarti A (2009). A genome-wide linkage and association scan reveals novel loci for autism. Nature 461: 802-808.

Weiss LA, Shen Y, Korn JM, Arking DE, Miller DT, Fossdal R et al (2008). Association between microdeletion and microduplication at 16p11.2 and autism. N Engl J Med 358: 667-675.

Weiss LA, Veenstra-Vanderweele J, Newman DL, Kim SJ, Dytch H, McPeek MS et al (2004). Genome-wide association study identifies ITGB3 as a QTL for whole blood serotonin. Eur J Hum Genet 12: 949-954.

Weng SJ, Carrasco M, Swartz JR, Wiggins JL, Kurapati N, Liberzon I et al (2011). Neural activation to emotional faces in adolescents with autism spectrum disorders. J Child Psychol Psychiatry 52: 296-305.

Werner E, Dawson G (2005). Validation of the phenomenon of autistic regression using home videotapes. Arch Gen Psychiatry 62: 889-895.

Williams G, King J, Cunningham M, Stephan M, Kerr B, Hersh JH (2001). Fetal valproate syndrome and autism: additional evidence of an association. Dev Med Child Neurol 43: 202-206.

Wisniowiecka-Kowalnik B, Nesteruk M, Peters SU, Xia Z, Cooper ML, Savage S et al (2010). Intragenic rearrangements in NRXN1 in three families with autism spectrum disorder, developmental delay, and speech delay. Am J Med Genet B Neuropsychiatr Genet 153B: 983-993.

Wood JJ, Drahota A, Sze K, Har K, Chiu A, Langer DA (2009). Cognitive behavioral therapy for anxiety in children with autism spectrum disorders: a randomized, controlled trial. J Child Psychol Psychiatry 50: 224-234.

Yan QJ, Rammal M, Tranfaglia M, Bauchwitz RP (2005). Suppression of two major Fragile X Syndrome mouse model phenotypes by the mGluR5 antagonist MPEP. Neuropharmacology 49: 1053-1066.

Yoder PJ, Lieberman RG (2010). Brief report: randomized test of the efficacy of picture exchange communication system on highly generalized picture exchanges in children with ASD. J Autism Dev Disord 40: 629-632.

Young MR, Kut JL, Coogan MP, Wright MA, Young ME, Matthews J (1993). Stimulation of splenic T-lymphocyte function by endogenous serotonin and by low-dose exogenous serotonin. Immunology 80: 395-400.

Zhang YQ, Friedman DB, Wang Z, Woodruff 3rd E, Pan L, O'Donnell J et al (2005). Protein expression profiling of the Drosophila fragile $X$ mutant brain reveals upregulation of monoamine synthesis. Mol Cell Proteomics 4: 278-290.

Zhao X, Leotta A, Kustanovich V, Lajonchere C, Geschwind DH, Law Ket al (2007). A unified genetic theory for sporadic and inherited autism. Proc Natl Acad Sci USA 104: 12831-12836.

Zhou J, Blundell J, Ogawa S, Kwon CH, Zhang W, Sinton C et al (2009). Pharmacological inhibition of mTORC1 suppresses anatomical, cellular, and behavioral abnormalities in neural-specific Pten knockout mice. $J$ Neurosci 29: 1773-1783. Showed that rapamycin inhibition of mTor signaling rescues multiple brain and behavioral phenotypes in mice lacking Pten in neurons.

Zhu C, Lindler KM, Campbell NG, Sutcliffe JS, Hewlett WA, Blakely RD (2011). Colocalization and regulated physical association of presynaptic serotonin transporters with A3 adenosine receptors. Mol Pharm 80: 458-465.

Zhu CB, Carneiro AM, Dostmann WR, Hewlett WA, Blakely RD (2005). p38 MAPK activation elevates serotonin transport activity via a traffickingindependent, protein phosphatase 2A-dependent process. J Biol Chem 280: 15649-15658.

Zhu CB, Lindler KM, Owens AW, Daws LC, Blakely RD, Hewlett WA (2010). Interleukin-1 receptor activation by systemic lipopolysaccharide induces behavioral despair linked to MAPK regulation of CNS serotonin transporters. Neuropsychopharmacology 35: 2510-2520. Connection between altered immune function and changes in SERT activity in vivo.

Zhu CB, Steiner JA, Munn JL, Daws LC, Hewlett WA, Blakely RD (2007). Rapid stimulation of presynaptic serotonin transport by $A(3)$ adenosine receptors. $J$ Pharmacol Exp Ther 322: 332-340. CNS A3 adenosine receptors demonstrated to regulate SERT function in nerve terminals vivo. 